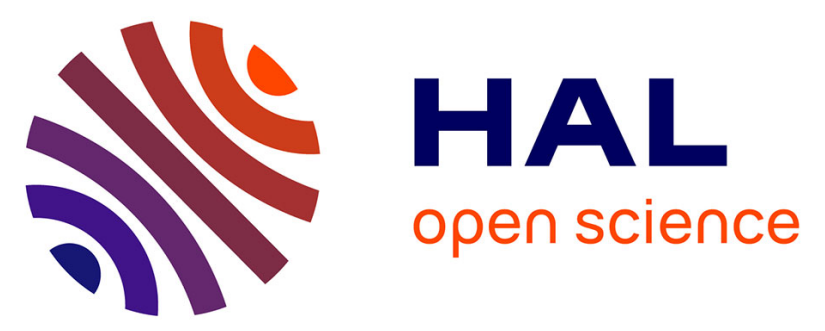

\title{
Performance improvement of the photocatalytic process for the degradation of pharmaceutical compounds using new POM/polymer photocatalysts
}

Chaima Brahmi, Mahmoud Benltifa, Mariem Ghali, Frédéric Dumur, Corine Simonnet-Jégat, Monnier Valérie, Fabrice Morlet-Savary, Latifa Bousselmi, Jacques Lalevée

\section{To cite this version:}

Chaima Brahmi, Mahmoud Benltifa, Mariem Ghali, Frédéric Dumur, Corine Simonnet-Jégat, et al.. Performance improvement of the photocatalytic process for the degradation of pharmaceutical compounds using new POM/polymer photocatalysts. Journal of Environmental Chemical Engineering, 2021, 9 (5), pp.106015. 10.1016/j.jece.2021.106015 . hal-03285144

\section{HAL Id: hal-03285144 \\ https://hal.science/hal-03285144}

Submitted on 13 Jul 2021

HAL is a multi-disciplinary open access archive for the deposit and dissemination of scientific research documents, whether they are published or not. The documents may come from teaching and research institutions in France or abroad, or from public or private research centers.
L'archive ouverte pluridisciplinaire HAL, est destinée au dépôt et à la diffusion de documents scientifiques de niveau recherche, publiés ou non, émanant des établissements d'enseignement et de recherche français ou étrangers, des laboratoires publics ou privés. 


\title{
Performance improvement of the photocatalytic process for the degradation of pharmaceutical compounds using new POM/ polymer photocatalysts
}

Chaima Brahmi $i^{\mathrm{a}, \mathrm{b}, \mathrm{c}, \mathrm{d}}$, Mahmoud Benltifa*c, Mariem Ghali ${ }^{\mathrm{a}, \mathrm{b}, \mathrm{c}, \mathrm{d}}$, Frédéric Dumur ${ }^{\mathrm{e}}$, Corine Simonnet-Jégat ${ }^{f}$, Monnier Valérie ${ }^{e}$, Fabrice Morlet-Savary ${ }^{a, b}$, Latifa Bousselmic ${ }^{c}$, Jacques Lalevée*a,b

a University of Haute-Alsace, CNRS, IS2M UMR 7361, F-68100 Mulhouse, France ${ }^{b}$ University de Strasbourg, France

${ }^{\mathrm{C}}$ Laboratory of Wastewaters and Environment, Center for Water Research and Technologies CERTE, BP 273, Soliman 8020, Tunisia

d University of Carthage, National Institute of Applied Sciences and Technology, Tunis 1080, Tunisia

e Aix Marseille Univ, CNRS, ICR, UMR7273, F-13397 Marseille (France)

${ }^{f}$ Institut Lavoisier de Versailles, UMR CNRS 8180, Université Paris Saclay, Université de Versailles St-Quentin en Yvelines, 45 Avenue des Etats-Unis, 78035 Versailles cedex, France

*Corresponding author: $\underline{\text { Jacques.lalevee@uha.fr and mahmoud.benltifa@certe.rnrt.tn }}$

\begin{abstract}
:
In the last few years, pharmaceuticals compounds classified as emergent pollutants have attracted the attention of many researchers, due to their massive presence in soil, surface, sewage, groundwater and drinking water, and to their harmful impacts on human's health and environment. In this context, the degradation of four drugs with different chemicals structures which are Ciprofloxacin, Oxytetracyclin, Ibuprofen and Erythromycin was investigated. Indeed, in this paper, we studied the impact of the presence in the aqueous solution of a newly developed POM/polymer composites on the removal of these different drugs from water. Synthetic details and characterization of these materials were previously reported by our group. The different experiments done in this work revealed that the presence of the phosphomolybdic acid-based composite was not essential for the total degradation of
\end{abstract}


Ciprofloxacin and Oxytetracyclin which could be totally removed from water by simple photolysis under UV lamp irradiation. However, under the same experimental conditions, the use of this photocatalyst was indispensable for the total mineralization of Ibuprofen which is more recalcitrant than the other chosen drugs. In fact, just $16 \%$ of this pharmaceutical was degraded by simple photolysis vs. $100 \%$ and $94 \%$ under $90 \mathrm{~min}$. of UV lamp and solar irradiation, respectively in the presence of the phosphomolybdicacid-based composite which was more pertinent than the usually used photocatalyst, namely titanium dioxide. Ibuprofen degradation pathway was identified thanks to mass spectrometry analysis, carried out at different times intervals. The obtained results demonstrated also that POM/polymer composite inhibits the degradation of Erythromycin by provoking the formation of more toxic intermediates than the original drug.

Keywords: photocatalysis, Polyoxometalate (POM) /Polymer composites, emergent pollutants...

\section{Introduction}

Recently, pharmaceutical products contaminating groundwater and threating nature and human health have received intensive attention from scientists. These new pollutants enter the aqueous environment from domestic and industrial wastewater ${ }^{1}$, affecting aquatic organisms ${ }^{2}$ and causing diseases by promoting antimicrobial resistance ${ }^{3}$.

One of the most prescribed drugs worldwide, is Ibuprofen which is a non-steroidal anti-inflammatory used as a fever reducer and a pain killer in tooth aches, migraine, muscular pain and inflammation conditions ${ }^{4,5}$. Antibiotics, are also excessively applied for humans and animal's medical treatments and additionally used in animals food to enhance their growth, to prevent and to control the apparition of serious diseases ${ }^{3}$. Indeed, Oxytetracyclin, Ciprofloxacin and Erythromycin are widely used antibiotics against numerous bacterial infections ${ }^{1}$. These pharmaceutical compounds selected for this study have different stable chemical structures and these molecules are present in wastewater and rivers in nonnegligible concentrations ${ }^{3,6}$, since an important part of the initial drug dose administrated to humans and animal's is exerted to the environment. Indeed, based on previous studies, the concentration of pharmaceuticals present in groundwater and surface water were generally less than $0.1 \mu \mathrm{g} / \mathrm{L}$ and those in treated water were lower than $0.05 \mu \mathrm{g} / \mathrm{L}^{7}$. The exposure to a 
random combination between these different chemicals is a menace for humans' life. Therefore, researchers have concentrated their efforts on removing these toxic pharmaceuticals from water.

Conventional treatments such as physical and chemical methods, biodegradation, chemical and electrochemical oxidation have been applied for the degradation of these different drugs ${ }^{1,3,8}$. However, these processes don't lead to a total mineralization of this products but most of the time transform them from one phase to another ${ }^{9}$. Hence, Advanced Oxidation processes (AOP), based on the production of highly reactive chemical including hydroxyl and superoxide anions radicals, have appeared as a new and performant technique for the total removal and mineralization of numerous emergent pollutants ${ }^{4,5,10}$.

Depending on the power and the emitting wavelengths of the irradiation sources, as well as the chemical structures and absorption spectra of the pollutants. Some of these chosen pharmaceuticals could be totally degraded with or without the presence of oxidative agents in the aqueous media. However, some others could require the presence of a photocatalyst to achieve a total mineralization. In this context, heterogenous photocatalysis based on semiconductors appeared as one of the most pertinent techniques when photocatalyst presents stability, non-toxicity, low-cost and oxidizing power leading to a total mineralization of the pollutant without the generation of toxic by-products ${ }^{9}$. Recently, researchers have focused their interest on this degradation process which was demonstrated by the bibliometric analysis below (Figure 1). In fact, about 3634 articles have been published between 2000 and 2020, with an increase in the publications number every five years reaching 2611 papers published in the last five years (See Figure 1).

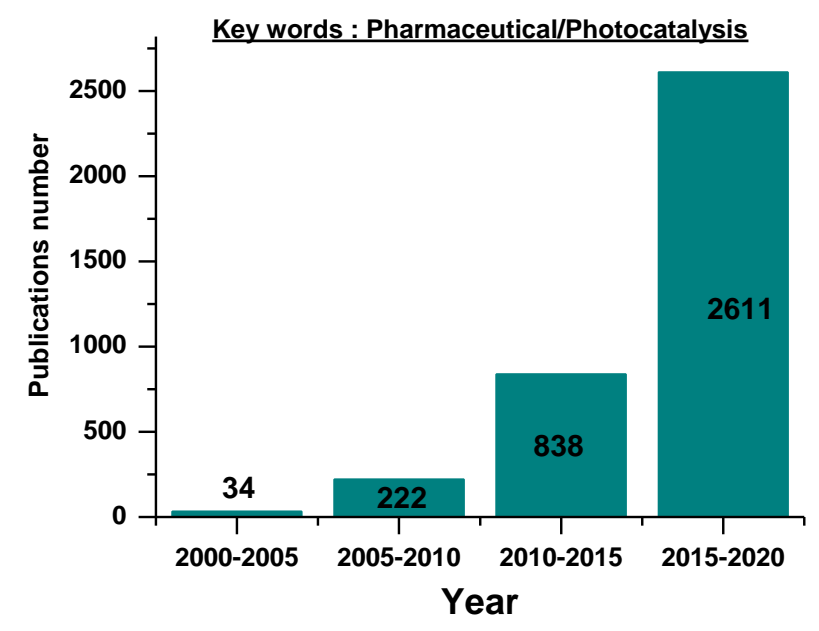


Figure 1. Bibliometric data using the keywords: Pharmaceuticals/Photocatalysis. Source: BibCNRS.

Titanium dioxide is the most used photocatalyst nowadays, however it absorbs only $4 \%$ of sunlight and is active in the UV range ${ }^{1}$. Polyoxometalates (POM) appeared as new visible-light photocatalysts thanks to their low toxicities and costs, their acidities and redox properties as well as their powerful absorptions of UV light at a longer wavelength than that done with $\mathrm{TiO}_{2}{ }^{11,12}$. However, these clusters are very soluble in aqueous solutions which limit their recyclability and their reusability ${ }^{12,13}$. As a solution, several studies have reported the association of POMs with several materials as counter ion ${ }^{14}, \mathrm{TiO}_{2}{ }^{15}$, silica gel ${ }^{16}$ and active carbon $^{17}$.

Recent works realized by our group have reported the immobilization of this catalyst into a polymer. In fact, different regenerable POM/polymer composites were synthesized by photopolymerization under visible light. The successful hybridization of POM/polymer was proved by several characterization techniques including Electron Microscopy, Energy Dispersive X-Ray Microscopy ${ }^{17,18}$. Moreover, these new developed materials were very efficient for the removal of Bisphenol-A from water under UV lamp and direct solar irradiation $^{19}$.

In the present study, we have investigated the removal of four pharmaceutical pollutants from aqueous solutions using the newly developed POM/polymer composites under different sources of irradiation. The chemicals degradation percentages were determined by UV-visible spectroscopy via the monitoring of their absorbances at different irradiation times. The obtained degradation kinetics were confirmed by mass spectrometry analysis which was also carried out at different irradiation times in order to identify the degradation mechanisms and to prove the total degradation of these pollutants.

\section{Experimental section}

\subsection{Chemical compounds}

$\mathrm{H}_{3} \mathrm{PMo}_{12} \mathrm{O}_{40}{ }^{20}, \mathrm{~W}_{10} \mathrm{O}_{32}$ (Thianthrenium) ${ }_{4}{ }^{21}$ were synthesized according to reported procedures. The monomer trimethyl-propane triacrylate (TMPTA) used for radical polymerization was purchased from Allnex. Bis(4-tert-butylphenyl) iodonium hexafluorophosphate (lod orSpeedcure938) and bis(2,4,6-trimethyl-benzoyl) phenylphosphine oxide (BAPO or 
speedcure BPO) were acquired from Lambson Ltd. Titanium dioxide used in this study and composed of a mixture of rutile and anatase, was obtained from $\mathrm{TCl}$. Ibuprofen ( $\alpha$-methyl-4(isobutyl)phenylacetic acid), Ciprofloxacin, Oxytetracyclin and Erythromycin were obtained from Sigma Aldrich. Chemical structures of the different reagents used in this study are shown in Figure 2. Physiochemical properties of the different pollutants studied in this work are presented in Table 1.

The synthesis of the $\mathrm{H}_{3} \mathrm{PMo}_{12} \mathrm{O}_{40}$ /polymer and $\mathrm{W}_{10} \mathrm{O}_{32}(\mathrm{TH})_{4} /$ polymer composites was detailed in our previous work. ${ }^{18}$, as well as the dimension, the BET surface area and the energy bandgap of the different prepared materials are gathered in Table 2.

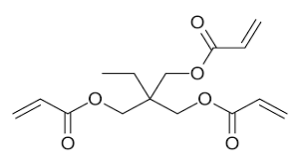

TMP

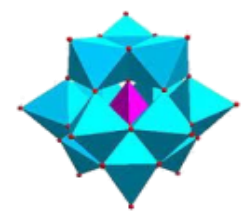

Polyoxometalate $\mathrm{H}_{3} \mathrm{PMO}_{12} \mathrm{O}_{40}$

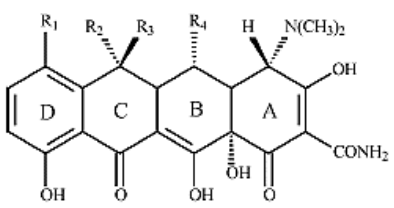

Oxytetracyclin

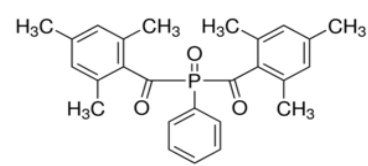

BAP

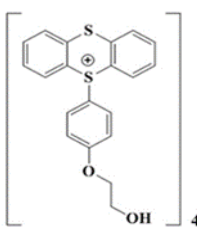

Polyoxometalate $\mathrm{W}_{10} \mathrm{O}_{32}(\mathrm{TH})_{4}$<smiles>O=C(O)c1cn(C2CC2)c2cc(N3CCNCC3)c(F)cc2c1=O</smiles>

Ciprofloxacin

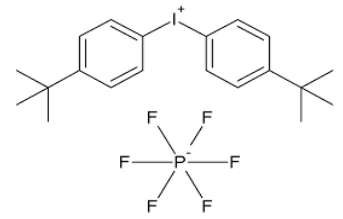

Iodonium salt

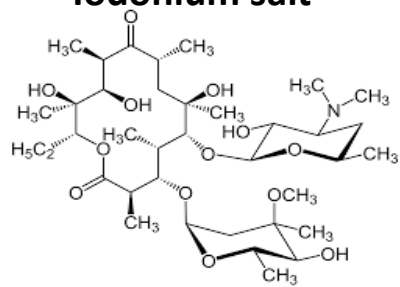

Erythromycin<smiles>CC(C)Cc1ccc(C(C)C(=O)O)cc1</smiles>

Ibuprofen

Figure 2. Chemical structures of the compounds used in this work.

Table 1. Physicochemical properties of the different pollutants degraded in this work.

\begin{tabular}{|c|c|c|c|c|c|c|c|}
\hline \multirow[t]{2}{*}{ Pollutants } & \multicolumn{7}{|c|}{ Physiochemical properties } \\
\hline & $\begin{array}{l}\text { Molecular } \\
\text { formula }\end{array}$ & $\begin{array}{l}\text { Molecula } \\
r \text { weight } \\
\text { (g/mol) }\end{array}$ & $\begin{array}{l}\text { Water } \\
\text { solubility } \\
\text { (mg/L) at } \\
25^{\circ} \mathrm{C}\end{array}$ & $\begin{array}{l}\text { Dissociatio } \\
\text { n constant } \\
(p K a)\end{array}$ & $\begin{array}{l}\text { Max } \\
\text { absorption } \\
(\mathrm{nm})\end{array}$ & $\begin{array}{l}\mathrm{pH} \text { in } \\
\text { water }\end{array}$ & $\begin{array}{l}\text { Concentrati } \\
\text { on }(\text { menol/t }\end{array}$ \\
\hline Ibuprofen & $\mathrm{C}_{13} \mathrm{H}_{18} \mathrm{O}_{2}$ & 206.28 & $21^{22}$ & $4.52^{22}$ & $222^{23}$ & 7.2 & 72.71 \\
\hline Ciprofloxacin & $\mathrm{C}_{17} \mathrm{H}_{18} \mathrm{FN}_{3} \mathrm{O}_{3}$ & 331.34 & $460^{24}$ & $6.68-8.63^{24}$ & $278^{25}$ & 6.3 & 45.27 \\
\hline
\end{tabular}




\begin{tabular}{lccccccc}
\hline Oxytetracyclin & $\mathrm{C}_{22} \mathrm{H}_{24} \mathrm{~N}_{2} \mathrm{O}_{9}$ & 460.43 & $313^{26}$ & $\begin{array}{l}3.57-7.49- \\
9.44^{27}\end{array}$ & $380^{26}$ & 6.1 & 32.57 \\
\hline Erythromycin & $\mathrm{C}_{37} \mathrm{H}_{67} \mathrm{NO}_{13}$ & 733.9 & $4.2^{26}$ & $8.9^{26}$ & $280(\mathrm{pH}=6.3)^{26}$ & 5 & 20.43 \\
\hline
\end{tabular}

Table 2: Band gap energy and BET surface area of the different developed materials ${ }^{17}$.

\begin{tabular}{|c|c|c|c|c|}
\hline \multirow[t]{2}{*}{ Characteristics } & \multicolumn{4}{|l|}{ Developed materials } \\
\hline & $\begin{array}{l}\mathrm{H}_{3} \mathrm{PMo}_{12} \mathrm{O}_{40} / \text { polymer } \\
\text { composite }\end{array}$ & $\begin{array}{l}\mathrm{W}_{10} \mathrm{O}_{32}(\mathrm{TH})_{4} / \text { polymer } \\
\text { composite }\end{array}$ & $\mathrm{TiO}_{2} /$ polymer & polymer \\
\hline Band gap energy (e.V) & 2.8 & 3.2 & 3.1 & 3.9 \\
\hline BET surface area $\left(\mathrm{m}^{2} \cdot \mathrm{g}^{-1}\right)$ & $1.3 \pm 0.11$ & $5.4 \pm 0.11$ & - & $9.3 \pm 0.37$ \\
\hline
\end{tabular}

\subsection{Irradiation Sources}

Photocatalytic degradation experiments were carried out under different light sources including, Light-Emitting Diodes (LED): LED@375 nm $\left(\mathrm{I}_{0}=70 \mathrm{~mW} / \mathrm{cm}^{2}\right)$, an Omnicure Dynamics lamp, Serie 1000 Lumen $\left(I_{0}=250 \mathrm{~mW} / \mathrm{cm}^{2}, \lambda=320-520 \mathrm{~nm}\right)$ and direct solar irradiation. The emission spectrum of the Omnicure lamp is shown in Figure S1 and the solar experiments were realized on July 24, 2019 at 2 PM, in Mulhouse, France, Northeast $30^{\circ}$, North $47^{\circ} 43^{\prime} 46^{\prime \prime}$, East $7^{\circ} 18^{\prime} 35^{\prime \prime}$ with an average intensity calculated for the entire solar spectrum of $682 \mathrm{~mW} / \mathrm{cm}^{2}$ provided by "Meteo Alsace" 28 . However, the intensity absorbed by the developed photocomposites during solar photolysis corresponds only to a fraction of the total solar energy presented above.

\section{Photocatalysis Experiments}

The concentration of the pharmaceutical pollutants samples was fixed to $15 \mathrm{mg} / \mathrm{L}$, which is a common concentration studied in literature, higher than those noticed generally in real effluents like mentioned in the introduction, and detectable by UV-visible absorption spectroscopy. Molar concentrations and measured $\mathrm{pH}$ of each pharmaceutical samples are presented in Table 2.

Photocatalytic degradation experiments were carried out directly in the photometer cell in the presence of $4 \mathrm{~mL}$ of the pharmaceutical pollutants and the POM/polymer composite shaped in the form of pellet. Monitoring of the chemicals concentrations was realized by following their absorbance over time with a JASCO V730 spectrophotometer. 


\section{Mass Spectroscopy Experiments}

Analyzes were carried out with a SYNAPT G2 HDMS (Waters) mass spectrometer equipped with a pneumatically assisted air pressure ionization (API) source. Mass spectra (MS) were obtained with a flight time analyzer (TOF). Exact mass measurement was done in triplicate with an external calibration. The sample provided in water at a concentration of $15 \mathrm{ppm}$ is diluted $1 / 10$ in a solution of methanol at $0.1 \mathrm{mM}$ of sodium chloride. The solution of the extract is introduced into the infusion ionization source at a flow rate of $10 \mu \mathrm{l} / \mathrm{min}$. Such analyses were reported in our previous works ${ }^{18}$.

\section{Results and discussions}

\section{Ciprofloxacin and Oxytetracyclin photocatalytic degradation}

Photocatalysis tests were carried out under a UV-Visible lamp irradiation, emitting lights at wavelengths between 320 and $520 \mathrm{~nm}$ with an intensity of $250 \mathrm{~mW} / \mathrm{cm}^{2}$.

UV-visible absorption spectra of Ciprofloxacin and Oxytetracyclin at different irradiation times with and without the presence of the phosphomolybdic acid-based composite are shown in Figure 3. 

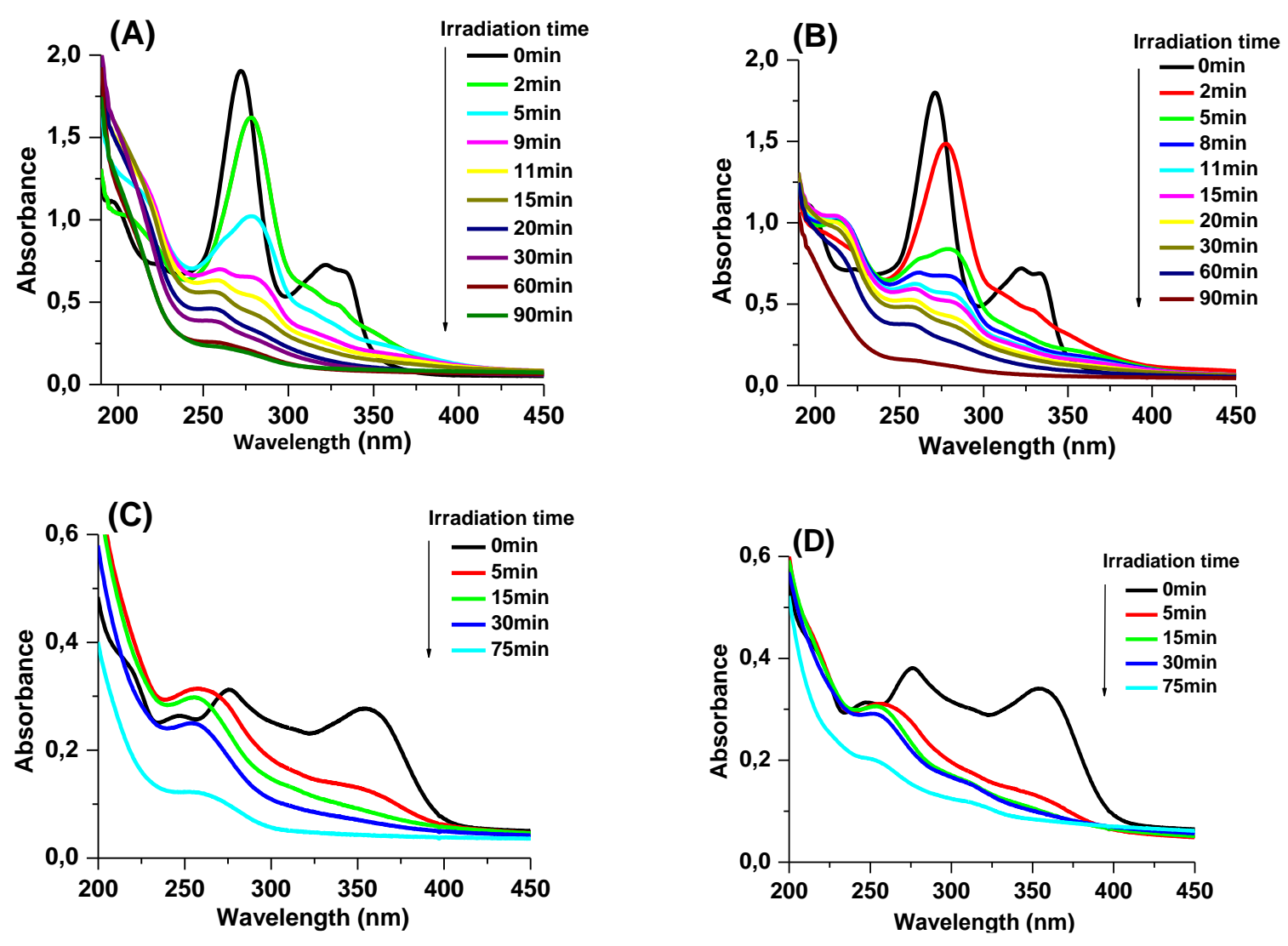

Figure 3. UV-visible absorption spectra of Ciprofloxacin (15ppm) in water at different irradiation time upon irradiation with a UV lamp light (A) in the presence of $\mathrm{H}_{3} \mathrm{PMo}_{12} \mathrm{O}_{40}$ /polymer composite; (B) Without the composite. UV-visible absorption spectra of Oxytetracyclin (15 ppm) in water at different irradiation times under UV lamp light (C) in the presence of $\mathrm{H}_{3} \mathrm{PMO}_{12} \mathrm{O}_{40} /$ polymer composite; (D) Without the composite.

Ciprofloxacin is characterized by two absorption peaks located at 272 and $330 \mathrm{~nm}$ corresponding respectively to $\pi \rightarrow \pi *$ transitions of fluorobenzene and quinolone ${ }^{29}$. These two bands gradually decrease by elongating the irradiation time (See Figure $3(A, B)$ ). The nonappearance of new absorption peaks reveals that no by-products absorbing at analytical wavelength appeared during the degradation ${ }^{19}$ (See Figure $\left.3(A, B)\right)$-Similarly, Oxytetracyclin is characterized by two absorption bands localized at 269 and $354 \mathrm{~nm}$ which correspond respectively to the chromophore $A$ and the system $B C D$ (See Figures 1 and $3(C, D))^{31}$. Intensities of these two absorption peaks undergo a gradual decrease with the appearance of a new peak at $260 \mathrm{~nm}$, confirming the presence of intermediates during the degradation process. Disappearance of all absorption peaks reflects the mineralization of this organic pollutant (See Figure 3 (C, D)). 
The pharmaceuticals concentrations were determined by monitoring the changes affecting the absorbance of the most intense peaks of Ciprofloxacin and Oxytetracyclin UVvisible spectra located respectively at 272 and $269 \mathrm{~nm}$ (See Figure 3). Therefore, as shown in Figure 4, the phosphomolybdic acid-based composite was not essential for the degradation of these pollutants, since high removal percentages were reached even in the absence of this photocatalyst. However, the final degradation percentages of Oxytetracyclin and Ciprofloxacin were slightly increased from 75 to $86 \%$ and from 88 to $90 \%$ in the presence of $\mathrm{POM} /$ polymer composite and after $75 \mathrm{~min}$ of the UV-visible lamp irradiation. Kinetics of the photocatalytic degradation reactions were studied and the results are gathered in Table 3.
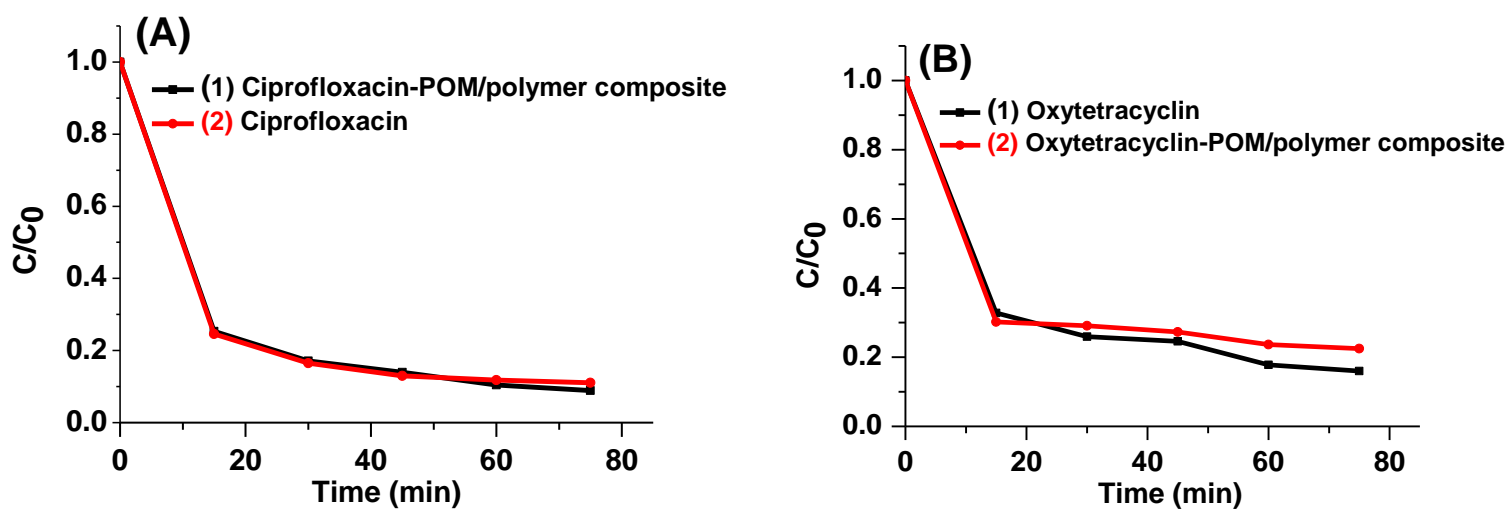

Figure 4. Monitoring of the concentration of $(A)(1)$ Ciprofloxacin in the presence of the phosphomolybdic acid-based composite , (2) Ciprofloxacin and (B) (3) Oxytetracyclin in the presence of the phosphomolybdic acid-based composite, (4) Oxytetracyclin, in water, under UV-lamp irradiation light. $[\mathrm{Oxy}]_{0}=15 \mathrm{mg} / \mathrm{L},[\mathrm{CIP}]_{0}=15 \mathrm{mg} / \mathrm{L}$.

Kinetics of Ciprofloxacin and Oxytetracyclin photocatalytic degradation in the presence or not of the phosphomolybdic acid-based composites were quantitively determined by fitting the zero order, pseudo first-order and pseudo second-order equations to the experimental data. These models are given by the following equations ${ }^{32}$ :

$$
\begin{gathered}
C_{0}-C=k_{a p p, 0} t \\
-\operatorname{Ln}\left(C / C_{0}\right)=k_{a p p, 1} t \\
\left(C_{0}-C\right) /\left(C^{*} C_{0}\right)=k_{a p p, 2 t}
\end{gathered}
$$

$\mathrm{C}_{0}$ and $\mathrm{C}$ designate respectively the pharmaceuticals initial concentrations and at time $t, k_{a p p, 0}$ is the zero-order rate constant $\left(\mathrm{mg} \mathrm{L}^{-1} \mathrm{~min}^{-1}\right), \mathrm{k}_{\mathrm{app}, 1}$ is the first-order rate constant $\left(\mathrm{min}^{-1}\right), \mathrm{k}_{\mathrm{app}, 2}$ 
is the second-order rate constant $\left(\mathrm{L} \mathrm{mg}^{-1} \mathrm{~min}^{-1}\right)$ and $\mathrm{t}$ the time. Therefore, $\mathrm{kapp}$ gives an indication of the activity of the catalyst. Results are gathered in Table S1.

As shown in Table S1, regression coefficients $\left(R^{2}\right)$ calculated based on the zero order and first-order reactions, are very low and ranged from 0.407 to 0.780 thus demonstrating that degradation kinetics of these pollutants does not follow the zero-order and pseudo-firstorder kinetics. Though, the regression coefficients calculated for the pseudo-second-order varying between 0.955 and 0.998 confirmed that these pharmaceuticals are degraded according to this kinetic model. Moreover, the obtained results confirmed also that the phosphomolybdic acid-based composite have slightly enhanced the degradation of the chosen two pollutants. Indeed, the second-order rate constants were increased from 0.113 to 0.243 $\mathrm{L} \mathrm{mg}^{-1} \mathrm{~min}^{-1}$ and from 0.055 to $0.073 \mathrm{~L} \mathrm{mg}^{-1} \mathrm{~min}^{-1}$, respectively in the cases of Oxytetracyclin and Ciprofloxacin (See Table S1).

In order to verify the obtained results by UV-visible absorption spectroscopy, the samples collected after 90 min of irradiation were analyzed by mass spectrometry. Figures 5 and 6 show that Ciprofloxacin $(\mathrm{m} / \mathrm{z}=332.1)$ is totally removed from water whether the presence or not of the phosphomolybdic acid-based composite in the aqueous solution. However, for the same irradiation time, the POM/polymer composite enhanced the mineralization of Oxytetracyclin. In fact, the disappearance of the characteristic peak of this pharmaceutical at $\mathrm{m} / \mathrm{z}=461.2$ after irradiation, in the presence of the photocatalyst, as shown in Figure 6 (B) confirms the total degradation of this pollutant. This peak persists in the absence of the composite proving that traces of this pollutant is still present in the aqueous media. 

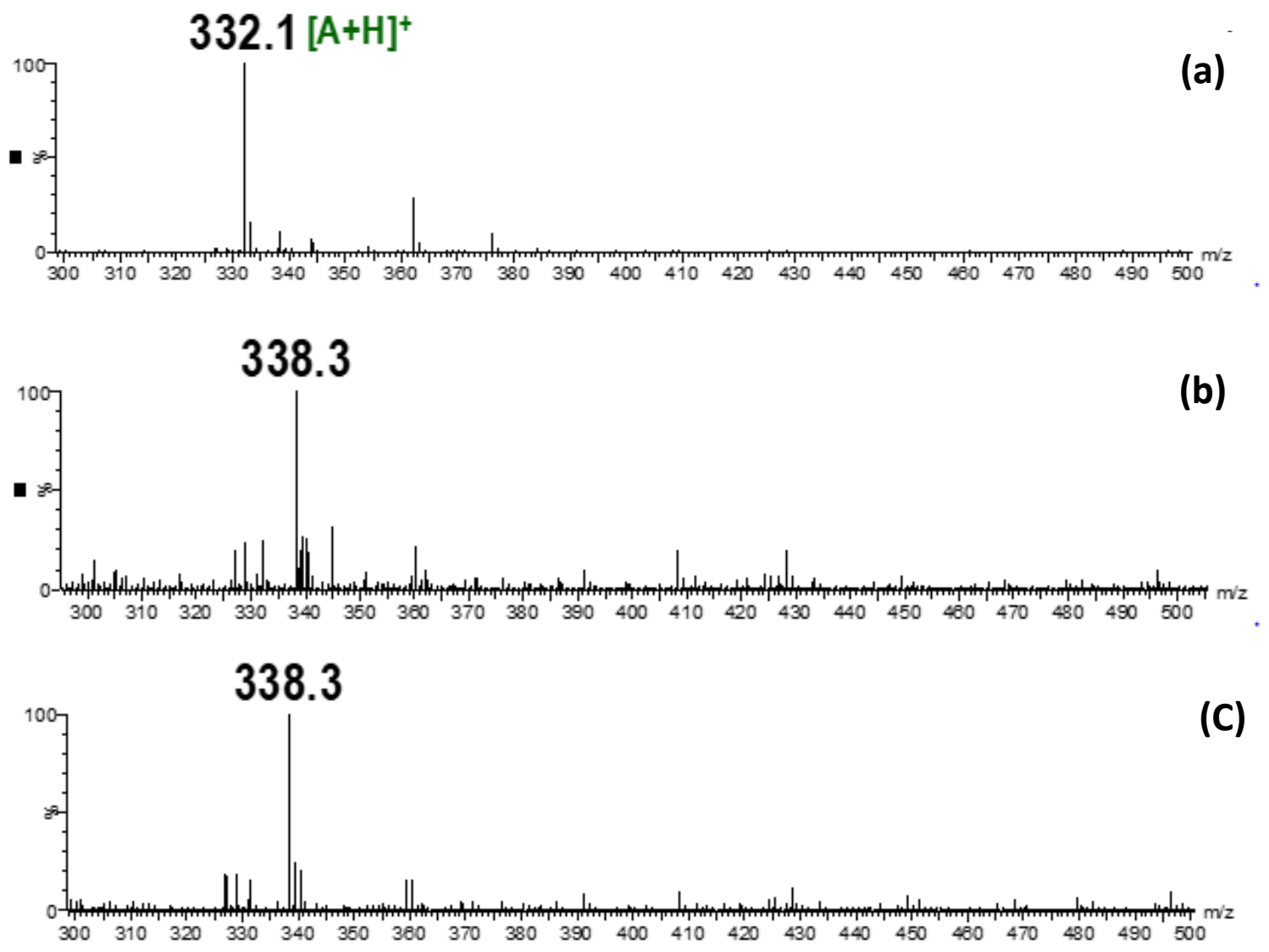

\section{3}

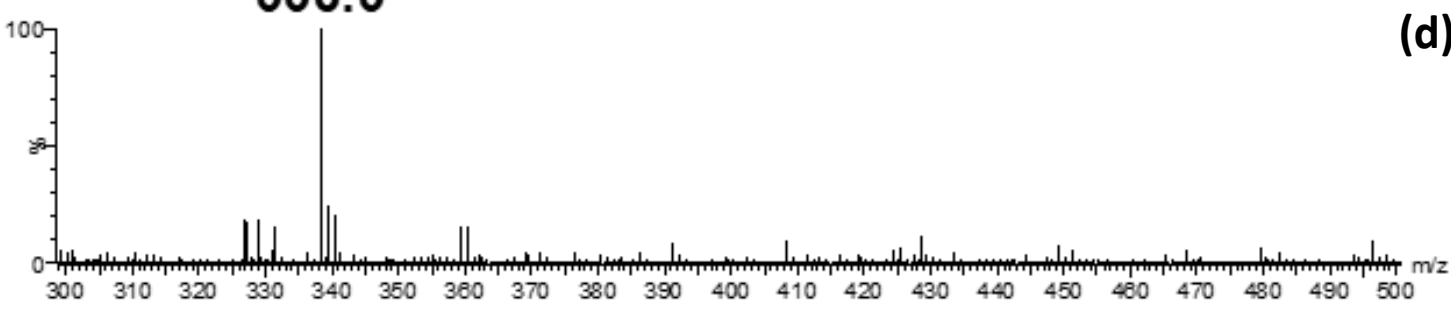

Figure 5. Positive electrospray mass spectrum of the Ciprofloxacin sample calibrated for exact mass measurement (targeted ion is detected at $\mathrm{m} / \mathrm{z}=332.1$ ), (a) before photolysis, (b) after photolysis in the absence of the $\mathrm{H}_{3} \mathrm{PMo}_{12} \mathrm{O}_{40}$ /polymer composite under UV lamp irradiation (c) after photocatalytic degradation in the presence of the $\mathrm{H}_{3} \mathrm{PMo}_{12} \mathrm{O}_{40}$ /polymer composite under UV lamp irradiation and (d) Positive electrospray mass spectrum of the analytical blank. 

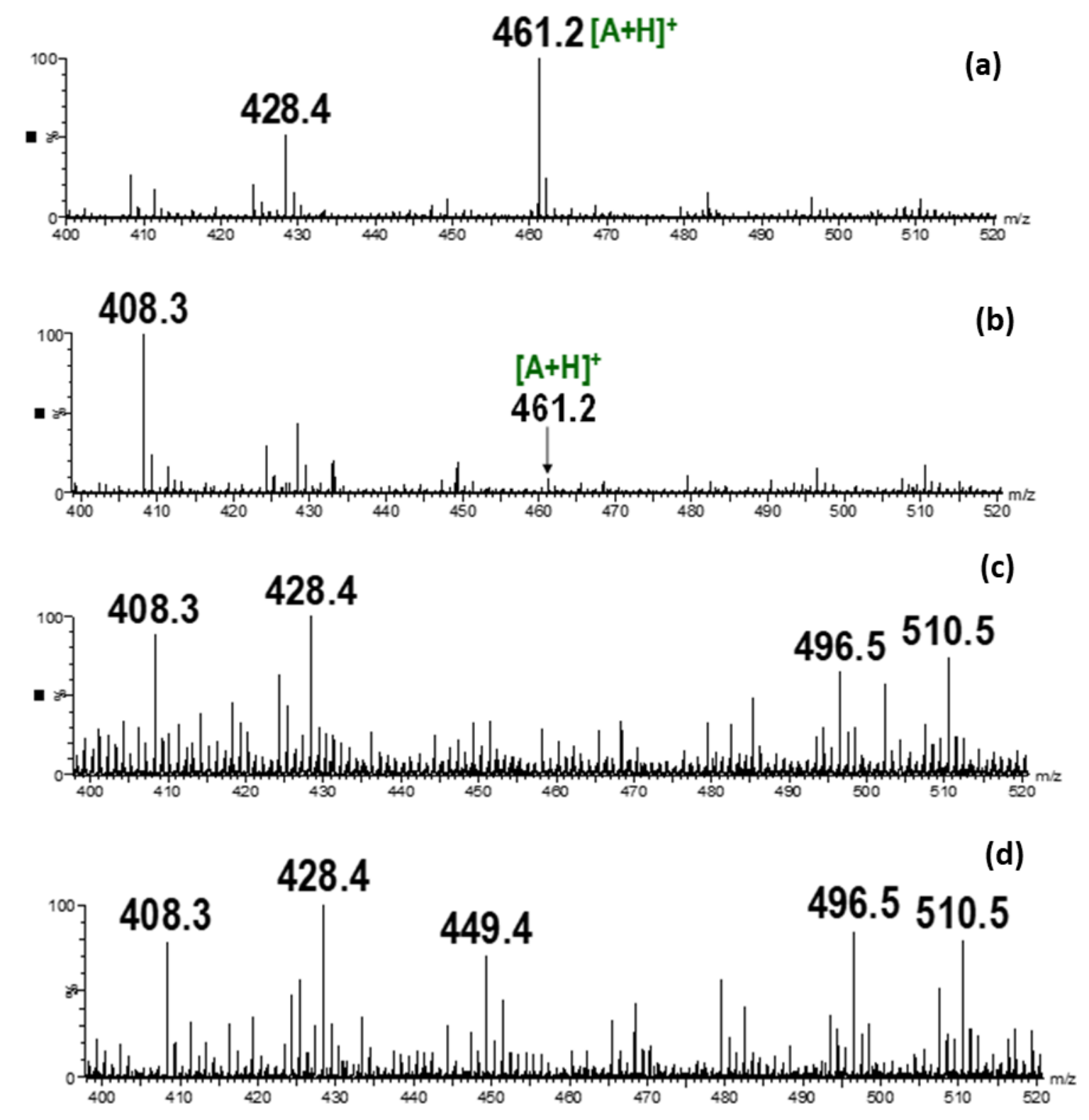

Figure 6. Positive electrospray mass spectrum of the Oxytetracyclin sample calibrated for exact mass measurement (targeted ion is detected at $\mathrm{m} / \mathrm{z}=461.2$ ), (a) before photolysis, (b) after photolysis in the absence of the $\mathrm{H}_{3} \mathrm{PMO}_{12} \mathrm{O}_{40}$ /polymer composite under UV lamp irradiation (c) after photocatalytic degradation in the presence of the $\mathrm{H}_{3} \mathrm{PMo}_{12} \mathrm{O}_{40}$ /polymer composite under UV lamp irradiation and (d) Positive electrospray mass spectrum of the analytical blank.

\section{Ibuprofen photocatalytic degradation}

In contrary to Ciprofloxacin and Oxytetracyclin which are totally decomposed under UV Lamp irradiation even in the absence of the POM/polymer composite, only $16 \%$ of 
Ibuprofen is removed from water under the same time and irradiation source. Hence, the use of this photocatalyst was indispensable for the total degradation and mineralization of this recalcitrant pollutant.
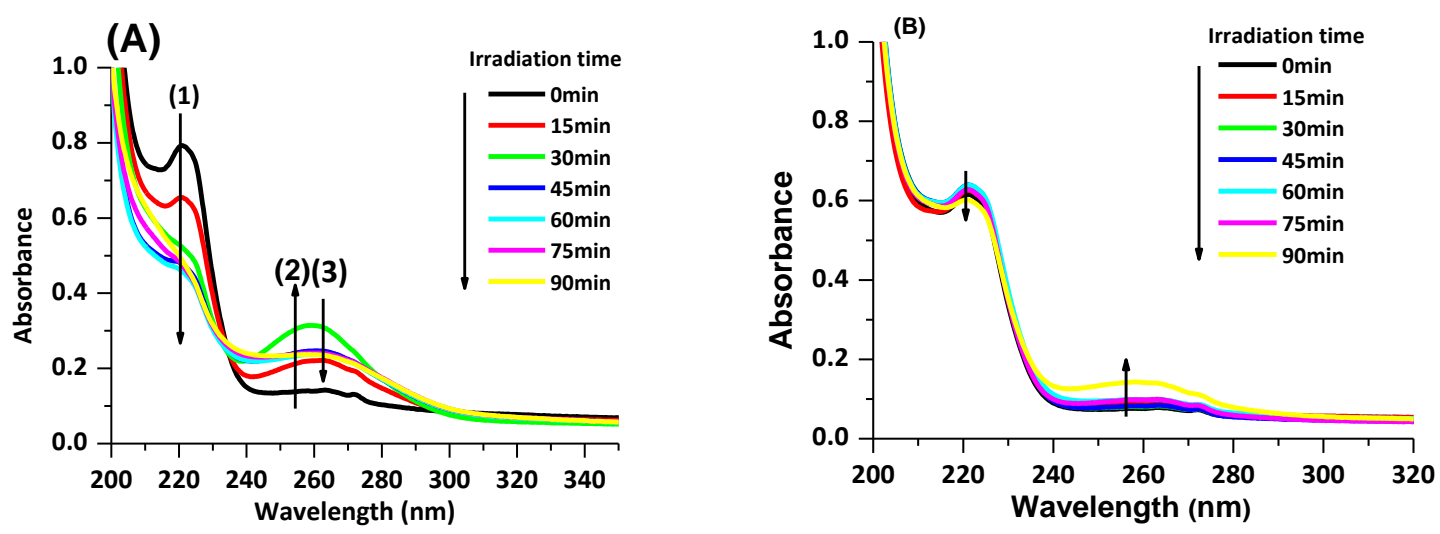

Figure 7. UV-visible absorption spectra of Ibuprofen (15ppm) in water at different irradiation times upon UV lamp irradiation: (A) in the presence of $\mathrm{H}_{3} \mathrm{PMO}_{12} \mathrm{O}_{40} /$ polymer composite, (B) Without the composite.

Progress of the photocatalytic abatement of Ibuprofen with the $\mathrm{H}_{3} \mathrm{PMo}_{12} \mathrm{O}_{40}$ /polymer composite was followed by monitoring the characteristic peak of this pharmaceutical located at $220 \mathrm{~nm}$ by UV-visible absorption spectroscopy. Figure 7 shows that the absorption peak of this drug at $220 \mathrm{~nm}$ which is related to the benzene ring decreased rapidly by increasing the irradiation time, indicating the photocatalytic degradation process of this pharmaceutical pollutant (See arrow 1). Moreover, a new red-shifted band near $262 \mathrm{~nm}$ appeared which strongly indicates the formation of reaction intermediates (See arrow 2). This by-product is probably a changed aromatic molecule such as products hydroxylated in the aromatic, or intermediates with new functional groups on the benzene ring such as olefins, alcohols and ketones, which are promoted by the attack of Ibuprofen by strong oxidant species such as hydroxyl radicals ${ }^{19,20}$. The formed band starts to arise immediately in the first period of photocatalytic treatment (after $5 \mathrm{~min}$ ), and reaches a maximum after $30 \mathrm{~min}$ of photocatalytic treatment and then decreases with the irradiation time, suggesting the decomposition of these intermediates (See arrow 3). The band in the $250-300 \mathrm{~nm}$ range disappears, indicating the decomposition of the aromatic structure. A characterless absorption band however remains. It is probably due to the absorbance of other by-products formed by a secondary degradation of the primary by-product ${ }^{19,20}$. 
To study the effect of the type of irradiation sources on the Ibuprofen photocatalytic degradation, solutions containing $15 \mathrm{ppm}$ of this pollutant in water were separately irradiated with a solar irradiation $\left(\lambda>290 \mathrm{~nm}, \mathrm{I}_{0}=682 \mathrm{~mW} / \mathrm{cm}^{2}\right)$, a UV lamp $\left(250 \mathrm{~mW} / \mathrm{cm}^{2}, \lambda=320-\right.$ $550 \mathrm{~nm})$ and a LED@375nm $\left(70 \mathrm{~mW} / \mathrm{cm}^{2}\right)$. The obtained results are presented in Figure 8.

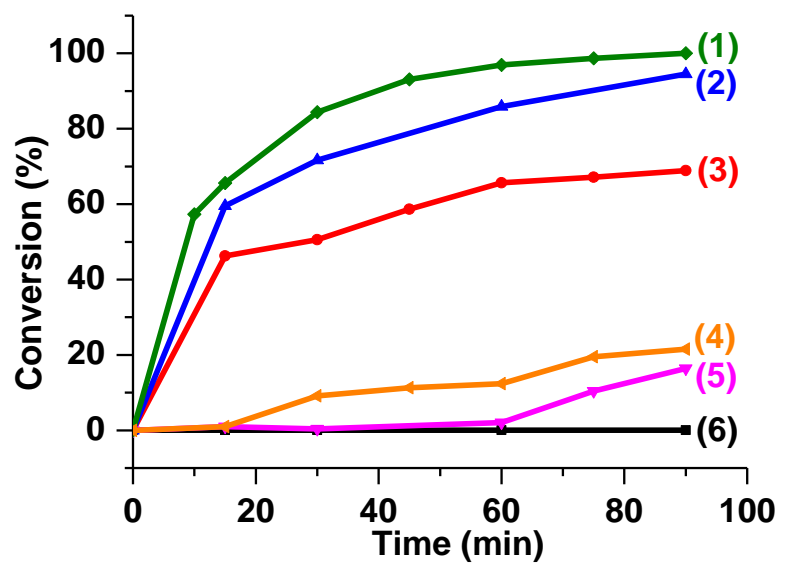

Figure 8. (A) Conversion of Ibuprofen in the presence of the phosphomolybdic acid-based composite under (1) UV Lamp, (2) sunlight, (3) LED@375 nm, and without the composite under (4) UV Lamp, (5) sunlight and (6) LED@375 nm. [IBU]0=15 ppm.

Figure 8 shows that the photolysis of Ibuprofen under the different irradiation sources and without the presence of any photocatalysts was low. Indeed, the concentration of this pharmaceutical hardly decreased by only $21 \%, 16 \%, 0.07 \%$ after 90 min of solar, UV lamp and LED@375nm irradiation, respectively. However, presence of the phosphomolybdic acid-based composite enhanced this pollutant conversion, reaching $94 \%, 100 \%$ and $69 \%$ under the same time and irradiation sources, respectively. These degradation percentages were confirmed by mass spectrometry analyses (See Table 3). Difference of efficiencies between the different irradiation sources can be explained by their irradiation intensities and their respective emission spectra. Indeed, the UV lamp and the solar irradiation are the most relevant ones thanks to their high irradiation power and the good overlap of their emission spectra with that of the composite absorption spectrum.

Table 3. Determination of Ibuprofen percentage removal from water by UV-visible absorption spectroscopy and mass spectrometry under different sources of irradiation. 


\begin{tabular}{ccc}
\hline & UV-visible spectroscopy & Mass spectrometry \\
\hline UV lamp & 100 & 100 \\
\hline Solar irradiation & 94 & 89 \\
\hline LED@375nm & 69 & 60 \\
\hline
\end{tabular}

Furthermore, the obtained results demonstrate that the composite has excellent photocatalytic activity for the degradation of Ibuprofen under different irradiation sources compared to other photocatalysts reported in the literature for the photocatalytic degradation of this pharmaceutical pollutant. In fact, Abdusalam and coworkers have degraded $99 \%$ of a 5 ppm ibuprofen solution in 200 min under visible light irradiation, using a surface modified $\mathrm{TiO}_{2}$ nanoparticle immobilized on polyacrylonitrile/multiwall carbon nanotubes ${ }^{21}$. Moreover, 70 and $80 \%$ of Ibuprofen present in aqueous solutions could be removed from water after $90 \mathrm{~min}$ of solar irradiation. These percentages have been reported by Muhammad Tanveer and coworkers who used $\mathrm{TiO}_{2}$ and $\mathrm{ZnO}$ photocatalysts respectively ${ }^{22}$.

The phosphomolybdic composite was selected as the photocatalyst model for the study of the effect of the irradiation sources on the removal of Ibuprofen and for the photocatalytic degradation of Ciprofloxacin and Oxytetracyclin, based on our previous works concerning the removal of Bisphenol-A from water in the presence of different POM/polymer composites, where the phosphomolybdic composite was identified as the most efficient one for this purpose ${ }^{19}$.

Therefore, in this paper, photocatalytic performance of the phosphomolybdic composite on the photocatalytic degradation of Ibuprofen wich of mesticient one for the removal of Bisphenol-A from water deduced from our previous works, was also compared to that of the decatungstate polyoxometalate and of the titanium dioxide in their powdered and composites forms, as $\mathrm{TiO}_{2}$ is the most widely used photocatalyst nowadays under UV light. However, it was impossible to include the $\mathrm{H}_{3} \mathrm{PMo}_{12} \mathrm{O}_{40}$ polyoxometalate in this comparison because of its high solubility in water and the superimposition of its absorption peak with that of the Ibuprofen pharmaceutical. All composites were synthesized under the same operating conditions. Obtained results are shown in Figure 9 and gathered in Table 4. 


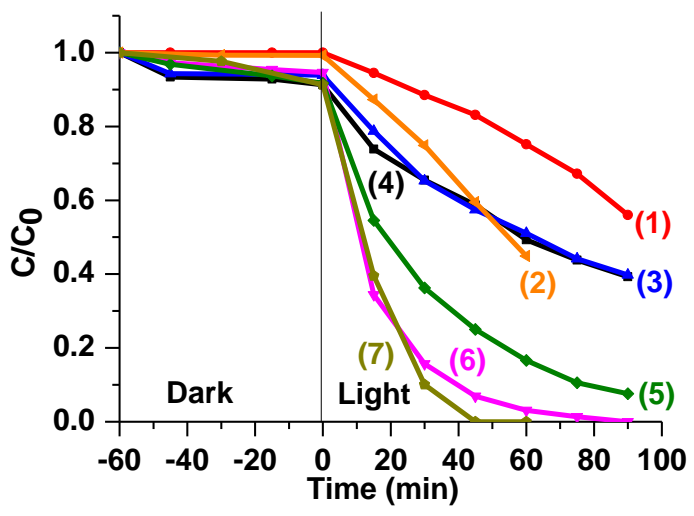

Figure 9. Ibuprofen photolysis (1) without photocatalysts presence and in the presence of (2) Suspended $\mathrm{TiO}_{2}$, (3) $\mathrm{TiO}_{2} /$ polymer composite, (4) Polymer, (5) $\mathrm{W}_{10} \mathrm{O}_{32}(\mathrm{TH})_{4} /$ polymer composite, (6) $\mathrm{H}_{3} \mathrm{PMo}_{12} \mathrm{O}_{40}$ /polymer composite and (7) Suspended $\mathrm{W}_{10} \mathrm{O}_{32}(\mathrm{TH})_{4}$, under UV lamp irradiation. $[\mathrm{IBU}]_{0}=15 \mathrm{ppm}$.

Kinetics of the Ibuprofen photolysis and catalytic photocatalytic degradation by the different developed materials was quantitatively investigated by fitting the apparent firstorder equation to the experimental data. This model is given by the following equation ${ }^{32}$ :

$$
-\operatorname{Ln}\left(C / C_{0}\right)=k_{a p p} t
$$

$C_{0}$ and $C$ designate respectively the Ibuprofen initial concentration and at time $t, k_{a p p}$ is the first-order rate constant $\left(\mathrm{min}^{-1}\right)$ and $\mathrm{t}$ the time. Therefore, $\mathrm{k}_{\mathrm{app}}$ gives an indication of the photocatalysis kinetic of the catalyst. Results are gathered in Table 4.

Table 4. Study of the Ibuprofen degradation kinetics by the different synthesized composites under UV lamp irradiation.

\begin{tabular}{lll}
\hline Materials & $\mathbf{K}_{\mathrm{app}}\left(\mathbf{m i n}^{-\mathbf{1}}\right)$ & $\mathbf{R}^{\mathbf{2}}$ \\
\hline $\mathrm{W}_{\mathbf{1 0}} \mathrm{O}_{\mathbf{3 2}}(\mathrm{TH})_{4}$ (Powder) & 0.073 & 0.964 \\
\hline $\mathrm{TiO}_{\mathbf{2}}$ (Powder) & 0.013 & 0.965 \\
\hline $\mathrm{H}_{3} \mathrm{PMO}_{12} \mathrm{O}_{40} /$ polymer & 0.056 & 0.999 \\
\hline $\mathrm{W}_{10} \mathrm{O}_{32}(\mathrm{TH})_{4} /$ polymer & 0.027 & 0.846 \\
\hline $\mathrm{TiO}_{2} /$ polymer & 0.009 & 0.989 \\
\hline Polymer & 0.009 & 0.990 \\
\hline lbuprofen photolysis & 0.006 & 0.945 \\
\hline
\end{tabular}

Apparently, the polymer, the phosphomolybdic acid, decatungstate and titanium dioxidebased composites as well as the powdered samples showed low adsorption capacities of 
Ibuprofen in the dark. Indeed, the low adsorption percentages of this pollutant ranged between $1 \%$ and $9 \%$ (See Figure 9). This could be explained by the small BET surface area of the different materials ${ }^{17}$ (See Table 2).

Furthermore, the comparative study between the different synthesized materials used for Ibuprofen removal from water presented in Figure 9 and Table 4, showed that the phosphomolybdic acid and decatungstate composites exhibit the highest Ibuprofen photocatalytic degradation under UV lamp irradiation. In fact, approximately $100 \%\left(K_{\text {app }}=\right.$ $\left.0.056 \mathrm{~min}^{-1}\right)$ and $92 \%\left(\mathrm{~K}_{\mathrm{app}}=0.027 \mathrm{~min}^{-1}\right)$ of this compound was removed by this two photocatalysts respectively, after 90 min of irradiation (See Figure 9 (curve 5, 6)). The better photocatalytic activity of the phosphomolybdic acid-based composite compared to that of the decatungstate composite was probably due to its lower energy bandgap ( $2.8 \mathrm{eV}$ ) (See Table 2) and to its higher redox potential and therefore to its easiness to be reduced (approximatively a difference of $0.4 \mathrm{~V}$ between the two composites) ${ }^{37,38}$. Indeed, a molybdate Kegging type polyoxometalate could accept between $1 \mathrm{e}^{-}$and $12 \mathrm{e}^{-}$. However, the decatungstate polyoxometalate can accept only 1 or $2 \mathrm{e}^{-38}$. Furthermore, thanks to their excellent redox properties as well as the lower energy bandgap in the case of the $\mathrm{H}_{3} \mathrm{PMo}_{12} \mathrm{O}_{40} /$ polymer composite, these two composites were more efficient than titanium dioxide/polymer composite. In fact, only $55 \%\left(K_{a p p}=0.009 \mathrm{~min}^{-1}\right)$ of the initial Ibuprofen concentration could be removed from water in the presence of the $\mathrm{TiO}_{2} /$ polymer composite compared to $\mathrm{POM} /$ composites $\left(84 \%\left(\mathrm{~K}_{\mathrm{app}}=0.027 \mathrm{~min}^{-1}\right)\right.$ and $\left.97 \%\left(\mathrm{~K}_{\mathrm{app}}=0.056 \mathrm{~min}^{-1}\right)\right)$ (See Figure 9 (curves $3,5,6)$ ). Moreover, in the presence of the neat polymer, approximatively $55 \%$ $\left(K_{\mathrm{app}}=0.009 \mathrm{~min}^{-1}\right)$ of this pharmaceutical was degraded. This could be due to the presence of the oxidant iodonium salt into the polymer, used as co-initiator for the free radical polymerization.

Remarkably, the photocatalytic performance of the different photocatalysts used in this work was reduced by their immobilization in the polymer. This was confirmed in the case of the decatungstate POM and $\mathrm{TiO}_{2}$, which have respectively removed $100 \%\left(\mathrm{~K}_{\mathrm{app}}=0.073 \mathrm{~min}^{-1}\right)$ and $56 \%\left(K_{a p p}=0.013 \mathrm{~min}^{-1}\right)$ of Ibuprofen after $60 \mathrm{~min}$ of UV lamp irradiation when they were used in suspension (See Figure 9 (curves 7, 2)) vs. 84\% $\left(K_{\mathrm{app}}=0.027 \mathrm{~min}^{-1}\right)$ and $50 \%\left(\mathrm{~K}_{\mathrm{app}}=\right.$ $0.009 \mathrm{~min}^{-1}$ ) in composite (See Figure 9 (curves 3,5$)$ ). This was probably due to the decrease of the photocatalysts active sites. 
In order to evaluate the newly synthesized POM/polymer composites photocatalytic performances on the Ibuprofen removal from water under UV lamp and solar irradiation, the average degradation reached by these materials, the active and specific surface area as well as the apparent kinetics constants $\left(\mathrm{K} \mathrm{min}^{-1}\right)$ were compared to those of the most relevant immobilized photocatalysts reported in the literature (between 2000 and 2020 (See Table 5)). To facilitate the comparison, a coefficient $D^{*}$ representing the ratio between average degradation rate and the active surface area of the immobilized photocatalysts, was calculated (Table 5: coefficient D*).

Table 5. Comparative study of the different immobilized photocatalysts used for the Ibuprofen photocatalytic degradation .

\begin{tabular}{|c|c|c|c|c|c|}
\hline Photocatalyst & Light source & $\begin{array}{l}\text { Average } \\
\text { degradation/Materia } \\
\text { I active surface } \\
\left(\mathrm{mg} \cdot \mathrm{min}^{-1} \cdot \mathrm{cm}^{-2}\right)\left(\mathrm{D}^{*}\right)\end{array}$ & $\begin{array}{l}\text { Specific } \\
\text { surface area } \\
\left(\mathrm{m}^{2} / \mathrm{g}\right)\end{array}$ & $k_{\text {app }}\left(\min ^{-1)}\right.$ & References \\
\hline \multirow[t]{2}{*}{$\mathrm{H}_{3} \mathrm{PMO}_{12} \mathrm{O}_{40} /$ polymer composite } & $\begin{array}{l}\text { UV light (250 } \\
\left.\mathrm{mW} / \mathrm{cm}^{2}\right)\end{array}$ & $3.55 \times 10^{-4}$ & 1.3 & $7.9 \times 10^{-2}$ & This work \\
\hline & $\begin{array}{l}\text { Sunlight (682 } \\
\left.\mathrm{mW} / \mathrm{cm}^{2}\right)\end{array}$ & $3.35 \times 10^{-4}$ & 1.3 & $3 \times 10^{-2}$ & This work \\
\hline $\mathrm{W}_{10} \mathrm{O}_{32}(\mathrm{TH})_{4} /$ polymer composite & $\begin{array}{l}\text { UV light ( } 250 \\
\left.\mathrm{~mW} / \mathrm{cm}^{2}\right)\end{array}$ & $3.29 \times 10^{-4}$ & 5.4 & $2.75 \times 10^{-2}$ & This work \\
\hline $\mathrm{TiO}_{2} /$ polymer composite & $\begin{array}{l}\text { UV light (250 } \\
\left.\mathrm{mW} / \mathrm{cm}^{2}\right)\end{array}$ & $2.16 \times 10^{-4}$ & - & $9.4 \times 10^{-3}$ & This work \\
\hline 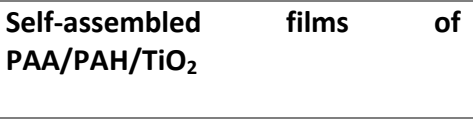 & $\begin{array}{l}\text { Xenon solar } \\
\text { simulator }(350 \\
\left.\mathrm{mW} / \mathrm{cm}^{2}\right)\end{array}$ & $1.67 \times 10^{-4}$ & - & - & 39 \\
\hline $\mathrm{TiO}_{2}$ activated borosilicate tube & $\begin{array}{l}\text { Solar simulator } \\
\left(50 \mathrm{~mW} / \mathrm{cm}^{2}\right)\end{array}$ & $1.22 \times 10^{-5}$ & - & $3 \times 10^{-3}$ & 40 \\
\hline $\begin{array}{l}\text { Immobilized } \mathrm{TiO}_{2} / \mathrm{ZnO} \text { sensitized } \\
\text { copper (II) }\end{array}$ & $\begin{array}{l}365 \mathrm{~nm} \text { UV light } \\
\left(1200 \mathrm{~mW} / \mathrm{cm}^{2}\right)\end{array}$ & $2.67 \times 10^{-5}$ & & $7 \times 10^{-3}$ & 41 \\
\hline $\begin{array}{l}\mathrm{PAN}-\mathrm{MWCNT} / \mathrm{TiO}_{2}-\mathrm{NH}_{2} \text { nanofiber } \\
\text { membrane }\end{array}$ & $\begin{array}{l}\text { UV-A lamp (315- } \\
400 \mathrm{~nm}), 40 \mathrm{~W}\end{array}$ & $2.18 \times 10^{-5}$ & - & - & 5 \\
\hline Immobilized $\mathrm{TiO}_{2}$ in a pilot plant & Solar light & $4.03 \times 10^{-6}$ & & $4.8 \times 10^{-2}$ & 42 \\
\hline \multirow[t]{2}{*}{$\begin{array}{lll}\mathrm{TiO}_{2}-\mathrm{rGO} & \text { (reduced } & \text { Graphene } \\
\text { Oxide) } & & \\
\end{array}$} & $\begin{array}{l}\text { Visible light } \\
\text { irradiation }\end{array}$ & $6.74 \times 10^{-7}$ & - & $7 \times 10^{-4}$ & 43 \\
\hline & $\begin{array}{l}\text { UV light } \\
\text { irradiation }\end{array}$ & $4.85 \times 10^{-6}$ & - & - & \\
\hline \multirow[t]{2}{*}{$\mathrm{TiO}_{2}-\mathrm{Fe}$} & $\begin{array}{l}\text { Visible light } \\
\text { irradiation }\end{array}$ & $1.73 \times 10^{-6}$ & - & $1.85 \times 10^{-3}$ & \\
\hline & $\begin{array}{l}\text { UV light } \\
\text { irradiation }\end{array}$ & $1.60 \times 10^{-6}$ & - & - & \\
\hline
\end{tabular}

D* was calculated by this paper's authors.

Interestingly, the developed POM/polymer composites displayed better ratios between the average degradation and the active catalysts surface area which corresponds to the calculated $D^{*}$, than those calculated for the most pertinent fixed catalysts already 
reported in the literature (Table 5). A factor of 10 to 100 differentiates the average degradation achieved by the materials studied in this work from those identified from the bibliographic research (See Table 5). Other factors can have a drastic effect on $D^{*}$ and are not considered here such as the intensity of the light source or the energy bandgap of the developed photocatalysts. However, we can assume that our newly synthesized photocatalysts have high efficiencies and performances for Ibuprofen photocatalytic degradation compared to those reported in Table 5.

Ibuprofen degradation percentages obtained by UV-visible absorption spectroscopy were confirmed by mass spectrometry (See Table 3). Moreover, the realization of mass spectra at different irradiation times during the Ibuprofen photocatalytic process allowed the identification of the different steps of the photocatalytic degradation mechanism (See Figure 11). Confirmation of the degradation kinetics was investigated under UV lamp irradiation via UV-visible absorption spectroscopy (See Table 6).

Table 6. Study of the Ibuprofen degradation kinetics by two different analysis methods: Mass spectrometry vs. UV-visible absorption spectroscopy, in the presence of the phosphomolybdic acid-based composite. [IBU $]_{0}=15$ ppm.

\begin{tabular}{lll}
\hline Methods & kapp $\left(\mathrm{min}^{-1}\right)$ & $\mathrm{R}^{2}$ \\
\hline UV-visible spectroscopy & 0.056 & 0.999 \\
Mass spectrometry & 0.049 & 0.939
\end{tabular}

Table 6 showed the monitoring of the Ibuprofen photocatalytic degradation via two different methods, namely UV-visible absorption spectroscopy and mass spectrometry. Apparent kinetic first order constants reached by the two analysis methods were almost similar $\left(0.056 \mathrm{~min}^{-1}\right.$ vs. $\left.0.049 \mathrm{~min}^{-1}\right)$.

The mineralization of Ibuprofen was verified by mass spectrometry analyses of different samples collected at the end of the photocatalytic process in the presence of the phosphomolybdic acid-based composite under UV lamp irradiation. Results are presented in Figure 10. 

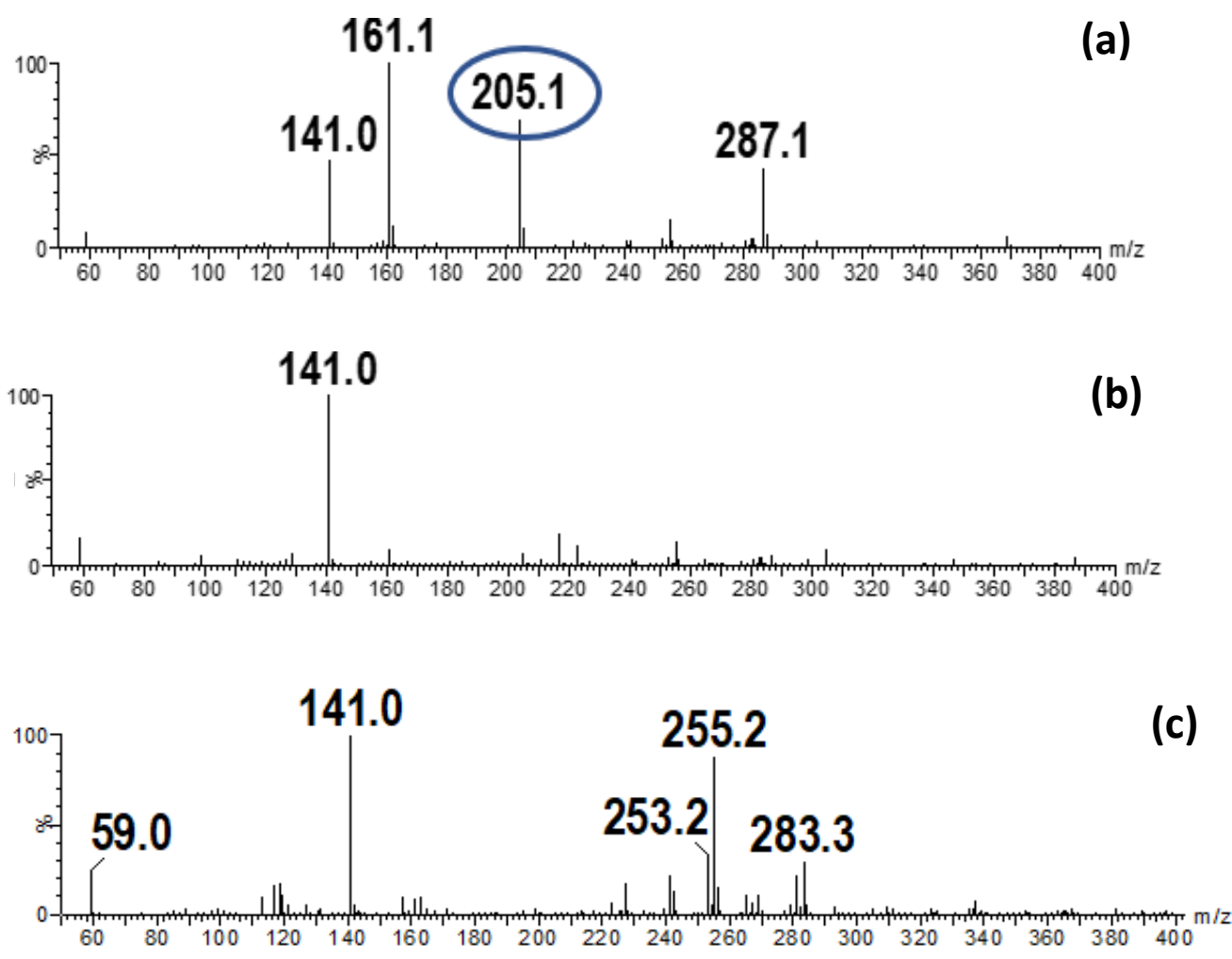

Figure 10. Negative electrospray mass spectrum of the Ibuprofen sample calibrated for exact mass measurement (targeted ion is detected at $\mathrm{m} / \mathrm{z}=205.1$ ), (a) before photolysis, (b) after catalytic photocatalytic degradation in the presence of the $\mathrm{H}_{3} \mathrm{PMo}_{12} \mathrm{O}_{40}$ /polymer composite under 90 min of UV lamp irradiation and (c) Negative electrospray mass spectrum of the analytical blank.

Figure 10 shows that the heterogeneous photocatalytic degradation of Ibuprofen operating under UV lamp irradiation promoted the total removal and the mineralization of this compound. In fact, disappearance of the Ibuprofen characteristic peak at $\mathrm{m} / \mathrm{z}=\mathbf{2 0 5 . 1}$ after the irradiation confirms the total degradation of this pollutant. Moreover, the total degradation of by-products formed during the photocatalytic process demonstrates the mineralization of this pollutant.

\section{Mechanism of the photocatalytic degradation}

In order to identify the Ibuprofen degradation route, the samples collected during the degradation experiments at different time intervals were analyzed by mass spectrometry. The HRMS data and the obtained mass spectra shown in Table 7 allowed to identify some intermediates arising from the photocatalytic degradation of Ibuprofen based on the literature, which are $I_{2}, I_{3}$ and $I_{4} \cdot I_{1}, I_{5}$ and $I_{6}$. 
Based on previous studies concerning ibuprofen mineralization, $\mathrm{I}_{1}\left(\mathrm{C}_{13} \mathrm{H}_{18} \mathrm{O}_{3}\right)$, which could be represented as two isomeric forms: $\alpha$-hydroxycarboxy-IBP and $\alpha$-hydroxy-isopropyl(BP), is formed by a hydroxyl radical attack and add to the ring or the side chain of Ibuprofen ${ }^{6,44,45}$. Subsequently, the decarboxylation of primary intermediate $I_{1}$ results in the formation of 4-isobuthylacetophenone $\left(I_{2}\right)$ which was identified by experiments analysis and previously reported in many works $\mathrm{s}^{34,46-48}$.

By extending the photolysis duration, the secondary by-product formed, undergoes continuously attacks by hydroxyl radicals leading to the formation of the intermediate $I_{3}$. Therefore, the decomposition of the compound $I_{3}$ forms two intermediates $I_{4}$ and $I_{5}{ }^{4}$. $I_{3}$ and $I_{4}$ are identified by mass spectrometry experiments and based on our knowledge, they are reported for the first time in this work. The repeatedly electrophile addition of hydroxyl radicals to the formed by-products induced benzene ring opening and then the mineralization of the initial pharmaceutical product by producing linear carboxylic acids with low molar mass and $\mathrm{CO}_{2}{ }^{4}$. The different identified intermediates via experimental mass spectrometry analysis and those deduced from the literature are gathered in Table 7.

The degradation mechanism presented in Figure 11, based on mass spectrometry analyses and deduced from the literature was in line with our previous work in which we have reported the photocatalytic POM/polymer composite mechanism based on hydroxyl radical production $^{18}$.

Table 7. Identification of the formed Intermediates during the Ibuprofen photocatalytic degradation.

\begin{tabular}{|c|c|c|c|c|c|c|}
\hline & Compound name & Formula & $\begin{array}{l}\text { Theoretical } \\
\mathrm{m} / \mathrm{z}\end{array}$ & $\begin{array}{l}\text { Measured } \\
\mathrm{m} / \mathrm{z}\end{array}$ & $\begin{array}{l}\Delta(p p \\
m)\end{array}$ & $\begin{array}{l}\text { refere } \\
\text { nce }\end{array}$ \\
\hline I & Ibuprofen & $\mathrm{C}_{12} \mathrm{H}_{16} \mathrm{O}_{4}$ & 224.16 & 224.16 & 0.9 & \\
\hline $\mathbf{I}_{1}$ & Hydroxy Ibuprofen & $\mathrm{C}_{13} \mathrm{H}_{18} \mathrm{O}_{3}$ & 222 & & & 15 \\
\hline$I_{2}$ & 4-isobutylacetophenone & $\mathrm{C}_{12} \mathrm{H}_{16} \mathrm{O}$ & 177.12 & 177.12 & 3 & 45 \\
\hline$I_{3}$ & $\begin{array}{l}\text { 1-[4-(1,2-dihydroxy-2- } \\
\text { methylpropyl)-2-hydroxyphenyl] } \\
\text { ethanone }\end{array}$ & $\mathrm{C}_{12} \mathrm{H}_{16} \mathrm{O}_{4}$ & 225.11 & 225.10 & 1 & \\
\hline$I_{4}$ & 2-Hydroxyisobutyric acid & $\mathrm{C}_{4} \mathrm{H}_{8} \mathrm{O}_{3}$ & 103.04 & 104.04 & 10 & \\
\hline$I_{5}$ & Phloroacetophenone & $\mathrm{C}_{9} \mathrm{H}_{8} \mathrm{O}_{4}$ & 125.02 & & & 4 \\
\hline$I_{6}$ & 1,6-Dideoxyhexo-2,5-diulose & $\mathrm{C}_{6} \mathrm{H}_{10} \mathrm{O}_{4}$ & 146 & & & 4 \\
\hline
\end{tabular}


<smiles>CC(C)Cc1ccc(C(C)C(=O)O)cc1</smiles>

$\mathrm{C}_{13} \mathrm{H}_{18} \mathrm{O}_{2}$

$\mathrm{MW}=206.13 \mathrm{~g} / \mathrm{mol}$
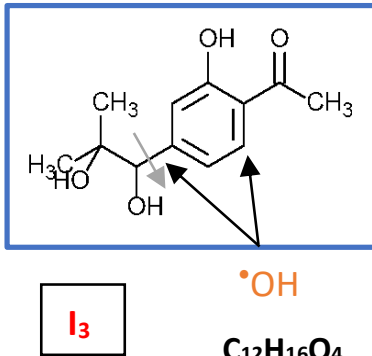

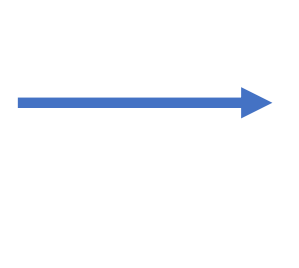

$\mathrm{C}_{13} \mathrm{H}_{18} \mathrm{O}_{3}$ $\mathrm{MW}=222 \mathrm{~g} / \mathrm{mol}$
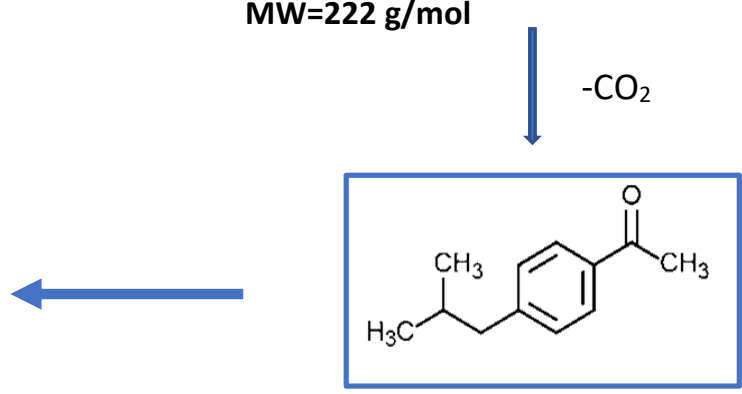

$$
\begin{gathered}
\mathrm{C}_{12} \mathrm{H}_{16} \mathrm{O} \\
\mathrm{MW}=176.12 \mathrm{~g} / \mathrm{mol}
\end{gathered}
$$

$\mathrm{MW}=224.1 \mathrm{~g} / \mathrm{mol}$

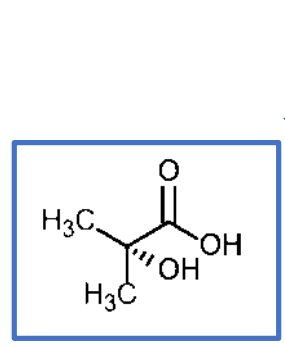

$\mathrm{I}_{4}$

$\mathrm{C}_{4} \mathrm{H}_{8} \mathrm{O}_{3}$ $\mathrm{MW}=104 \mathrm{~g} / \mathrm{mol}$

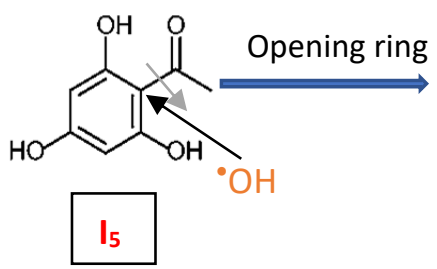

$\mathrm{C}_{8} \mathrm{H}_{8} \mathrm{O}_{4}$ $\mathrm{MW}=168 \mathrm{~g} / \mathrm{mol}$

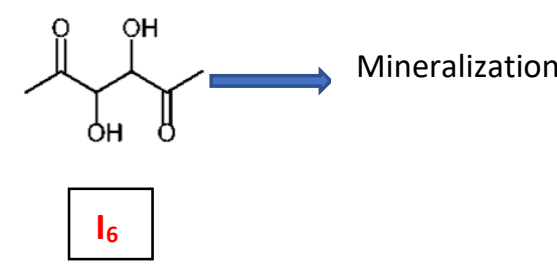

$\mathrm{C}_{6} \mathrm{H}_{10} \mathrm{O}_{4}$ $\mathrm{MW}=146 \mathrm{~g} / \mathrm{mol}$

Figure 11. Ibuprofen proposed degradation mechanism.

\section{Erythromycin photocatalytic degradation}

Erythromycin is one of the most prescribed antibiotics worldwide, used for the treatment of different infections ${ }^{49}$. Due to its toxicity and abundant presence in groundwater, removing it from water by our new developed POM/polymer composites seemed to be an interesting approach. Obtained results are shown in Figure 12. 

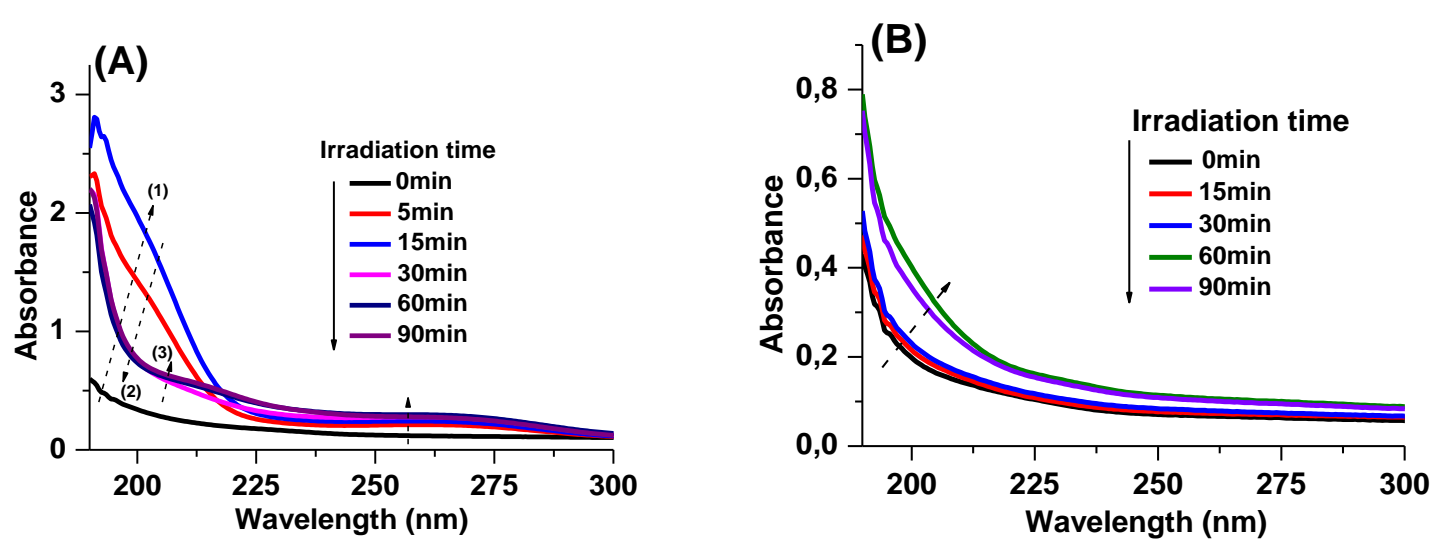

Figure 12. UV-visible absorption spectra of the Erythromycin (15ppm) in water at different irradiation times upon UV lamp irradiation: $(A)$ in the presence of the $\mathrm{H}_{3} \mathrm{PMo}_{12} \mathrm{O}_{40}$ /polymer composite and (B) Without the composite.

Figure $12(A)$ shows that the modification of the absorption spectra of Erythromycin with increasing the irradiation time in the presence of the $\mathrm{H}_{3} \mathrm{PMo}_{12} \mathrm{O}_{40}$ /polymer composite clearly indicates the formation of reactions intermediates. In fact, the absorbance at $210 \mathrm{~nm}$ starts to arise immediately at the beginning of the photocatalytic treatment and reaches a maximum after $15 \mathrm{~min}$ of irradiation and then decreased, due to the decomposition of the formed by-product.

However, the Erythromycin photolysis absorption spectra in water in the absence of the composite (Figure 12 (B)), haven't undergone the same spectral changes. Indeed, a slight increase in the absorbance at $210 \mathrm{~nm}$ was noticed. These results suggest that this antibiotic dissolved in pure water did not photodegradate in the same way under UV lamp irradiation in the presence or not of the phosphomolybdic acid-based composite.

As the UV-visible absorption spectra cannot be used to monitor the degradation of the pollutant as the newly formed intermediaries are absorbing in the same range than the phosphomolybdic acid-based composite. In order to confirm the Erythromycin photocatalytic degradation and to identify the formed intermediates, mass spectrometry analyses were carried out before and at the end of the irradiation process. Results are shown in Figure 13. 

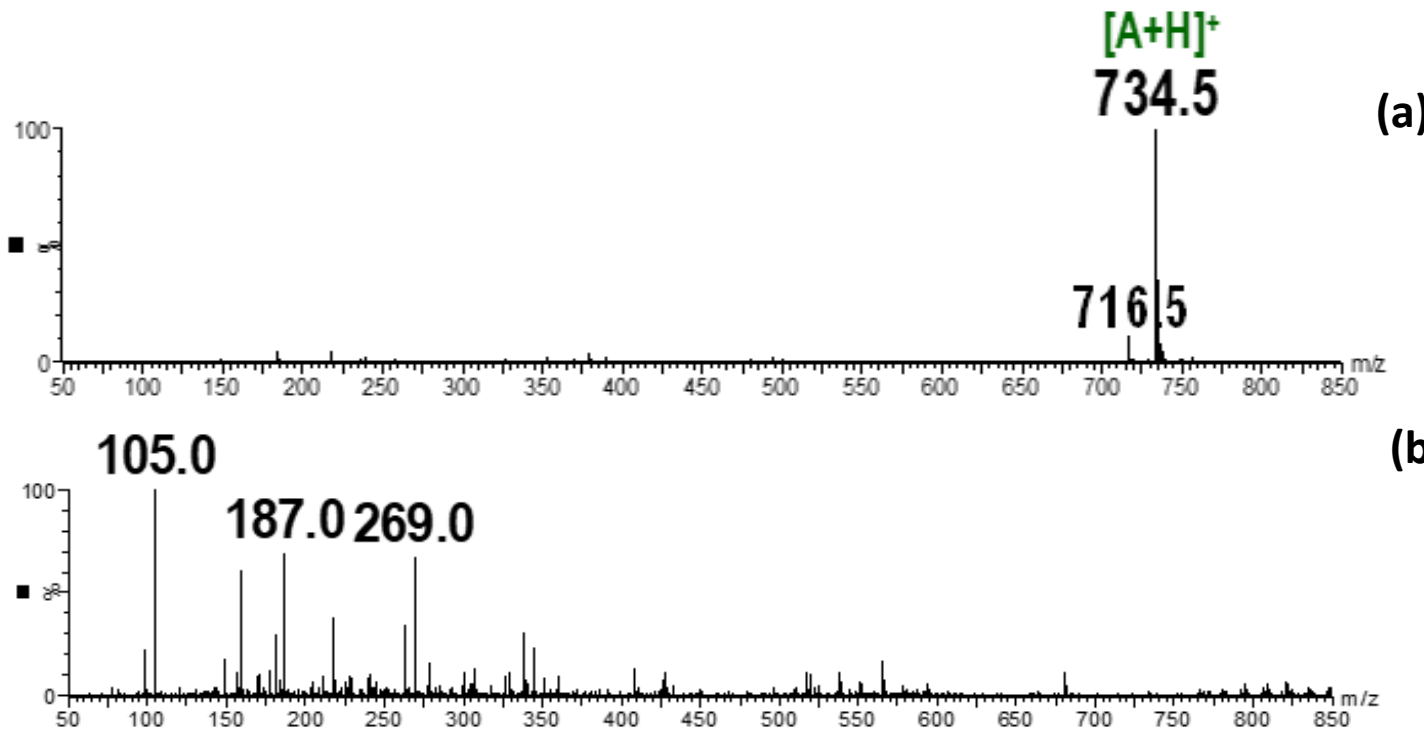

(b)
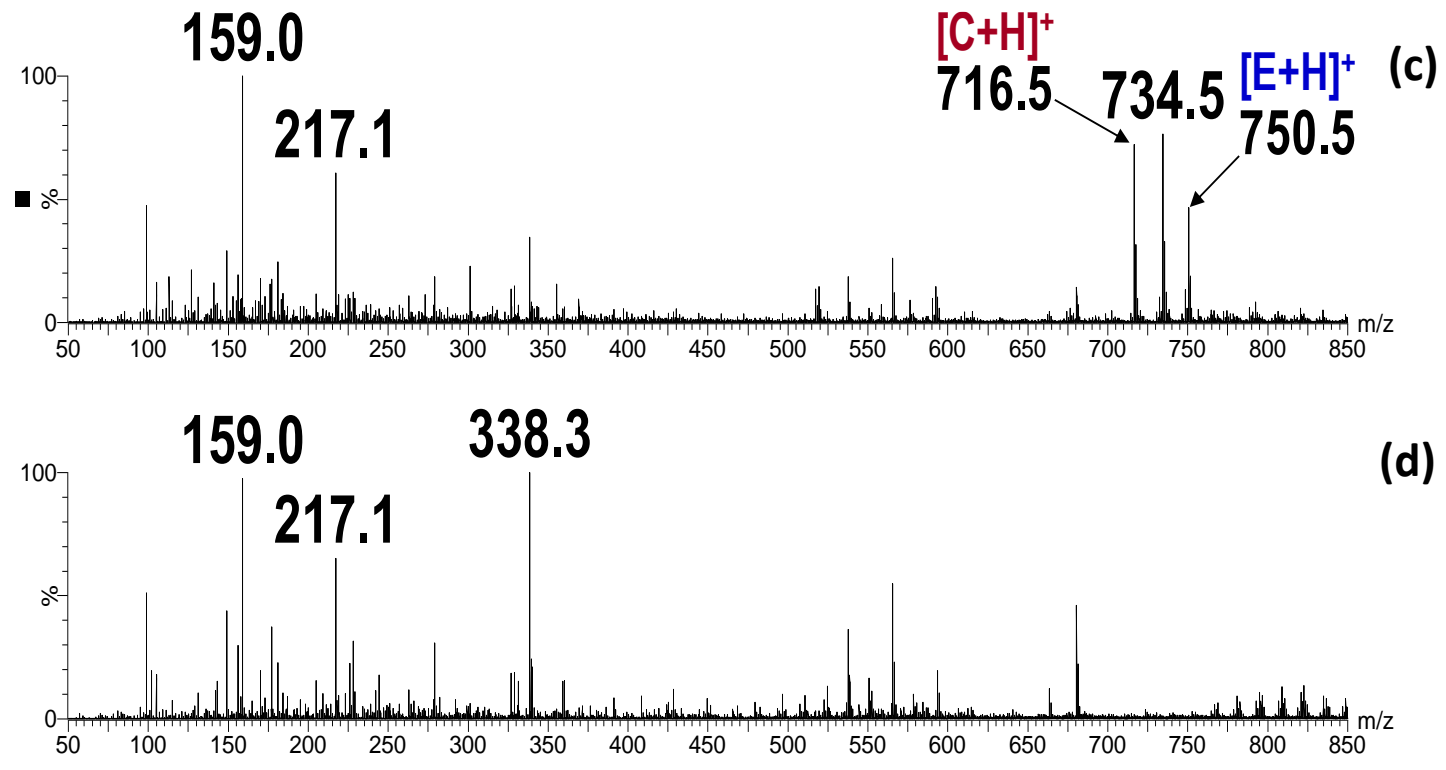

Figure 13. Positive electrospray mass spectrum of the Erythromycin sample calibrated for exact mass measurement (targeted ion is detected at $\mathrm{m} / \mathrm{z}=734.5$ ), (a) before photolysis, (b) after photocatalytic degradation in the absence of the $\mathrm{H}_{3} \mathrm{PMo}_{12} \mathrm{O}_{40}$ /polymer composite under 90 min of UV lamp irradiation, (c) after photocatalytic degradation in the presence of the $\mathrm{H}_{3} \mathrm{PMo}_{12} \mathrm{O}_{40} /$ polymer composite under $90 \mathrm{~min}$ of UV lamp irradiation and (c) Positive electrospray mass spectrum of the analytical blank.

Figure 13 (b) shows that the Erythromycin photolysis under a UV lamp irradiation without the POM/polymer composite presence, promoted the total removal and the mineralization of this compound. In fact, the disappearance of the characteristic peak of Erythromycin at $\mathrm{m} / \mathrm{z}=734.5$ after the irradiation confirms the total degradation of this pollutant. However, in the presence of the $\mathrm{H}_{3} \mathrm{PMo}_{12} \mathrm{O}_{40}$ /polymer composite, only $94 \%$ of this 
antibiotic was removed from water (See Figure 13 (c)). Moreover, the Erythromycin A dihydrate and the Erythromycin $\mathrm{F}$ have been identified by mass spectrometry analyses as byproducts with a mass error less than $1 \mathrm{ppm}$. These intermediates were previously reported by Voigt and coworkers who studied the photocatalytic degradation kinetics of azithromycin, erythromycin and tylosin and their transformation products ${ }^{50}$. Tae-Kyoung Kim and coworkers have also reported the generation of these two by-products during the photocatalytic treatment of Erythromycin with chlorine. Furthermore, they studied their toxicities and noticed that Erythromycin A dihydrate (by-product 1 ) has higher toxicity than Erythromycin whereas Erythromycin $\mathrm{F}$ (by-product 2) has lower toxicity ${ }^{49}$. Therefore, presence of the phosphomolybdic acid-based composite in solution decreased the Erythromycin mineralization rate and led to the production of toxic intermediates after 90 min of treatment. Consequently, the heterogenous photocatalytic treatment of this antibiotic is less effective than its simple photolysis. A partial degradation pathway of Erythromycin in the presence of the POM/polymer composite and under Omnicure lamp irradiation is proposed in Figure 14 based on mass spectrum analyses and the literature ${ }^{49,50}$. By-product 1 is a result of a dehydration of the initial compound and by-product 2 is formed by a hydroxyl attack.

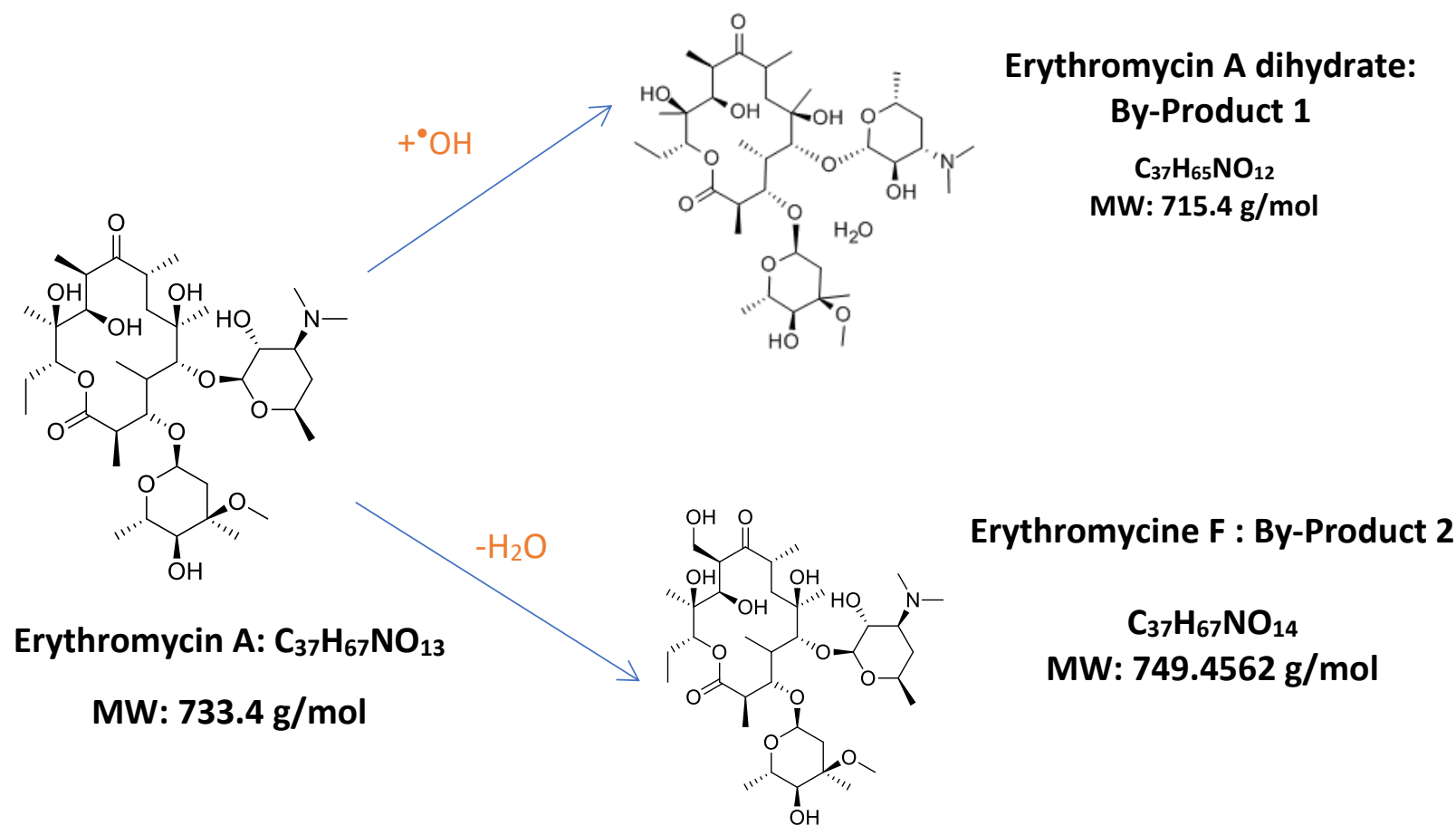

Figure 14. Suggested photocatalytic degradation pathway of the Erythromycin under UV Lamp irradiation, in the presence of the phosphomolybdic composite. 


\section{Conclusions}

Since the presence of pharmaceuticals compounds in groundwater is a serious problem threating human health and environment, the degradation of Ciprofloxacin, Oxytetracycline, Ibuprofen and Erythromycin was investigated in this work based on UVvisible absorption spectroscopy and mass spectrometry analyses.

In this study, the effectiveness of our new developed POM/polymer composites for the removal of the different pharmaceuticals from water was investigated. Synthesis details and characterization of this photocatalyst material have been previously reported by our $\operatorname{group}^{18,17}$.

Experiments have proved that Ciprofloxacin and Oxytetracyclin are totally degraded under UV lamp irradiation even without the POM/polymer composites presence. However, only $16 \%$ of Ibuprofen was removed from water under $90 \mathrm{~min}$ of the same irradiation source. Hence, the use of this photocatalyst was indispensable for the total degradation and mineralization of this recalcitrant pollutant under different irradiation sources including solar irradiation, UV lamp and LED@375nm. Degradation mechanism of this pharmaceutical have also been identified by realizing mass spectrometry analysis at different irradiation times during the photocatalytic process. Furthermore, the obtained results demonstrate also that the POM/polymer composites were not essential for the complete degradation of Erythromycin. In fact, no enhancement of the photodegradation kinetics was observed in the presence of this photocatalyst which leads also to the formation of more toxic intermediates than the original drug.

In conclusion, heterogenous photocatalytic treatment is a powerful way to mineralize some recalcitrant pollutants such as Ibuprofen. However, depending on the target pollutant absorption area and the irradiation sources emission spectrums, simple photolysis could be more effective to obtain total mineralization. 
TOC graphic

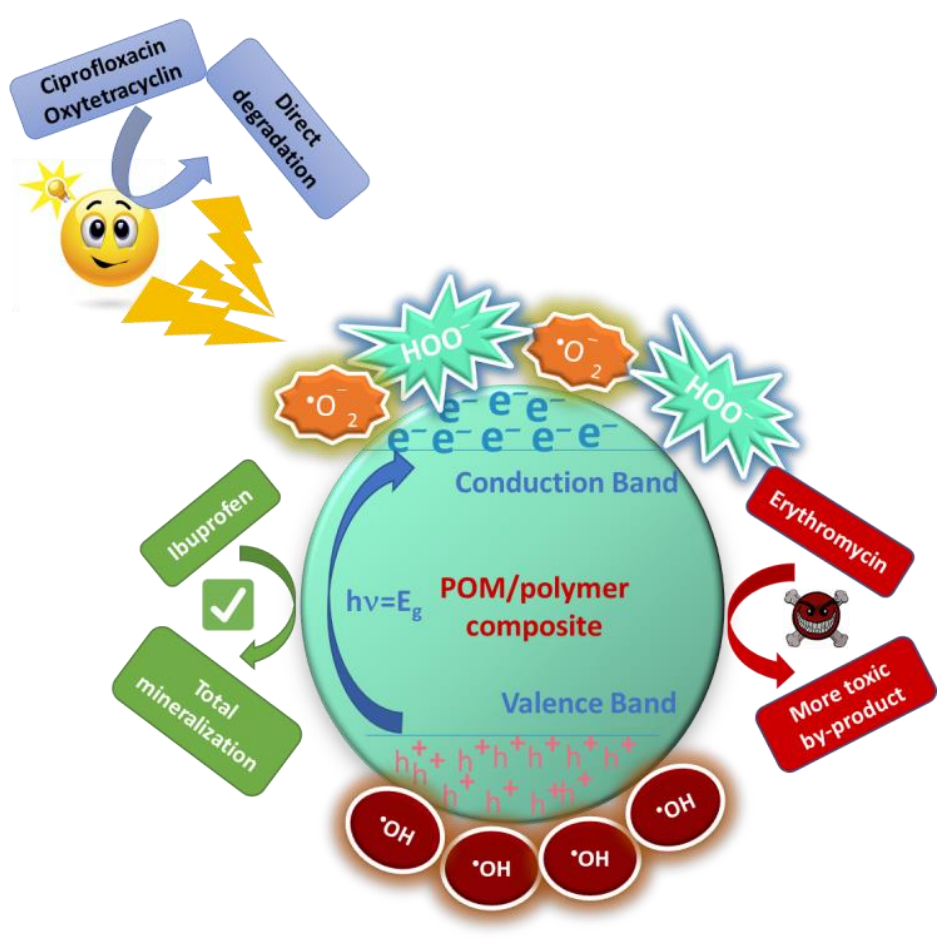




\section{References}

(1) Sarafraz, M.; Sadeghi, M.; Yazdanbakhsh, A.; Amini, M. M.; Sadani, M.; Eslami, A. Enhanced Photocatalytic Degradation of Ciprofloxacin by Black Ti3+/N-TiO2 under Visible LED Light Irradiation: Kinetic, Energy Consumption, Degradation Pathway, and Toxicity Assessment. Process Safety and Environmental Protection 2020, 137, 261-272. https://doi.org/10.1016/j.psep.2020.02.030.

(2) González-Pérez, B. K.; Sarma, S. S. S.; Nandini, S. Effects of Selected Pharmaceuticals (Ibuprofen and Amoxicillin) on the Demography of Brachionus Calyciflorus and Brachionus Havanaensis (Rotifera). The Egyptian Journal of Aquatic Research 2016, 42 (3), 341-347. https://doi.org/10.1016/j.ejar.2016.09.003.

(3) Ahmadi, M.; Ramezani Motlagh, H.; Jaafarzadeh, N.; Mostoufi, A.; Saeedi, R.; Barzegar, G.; Jorfi, S. Enhanced Photocatalytic Degradation of Tetracycline and Real Pharmaceutical Wastewater Using MWCNT/TiO2 Nano-Composite. Journal of Environmental Management 2017, 186, 55-63. https://doi.org/10.1016/j.jenvman.2016.09.088.

(4) Kumar, A.; Sharma, G.; Naushad, M.; Al-Muhtaseb, A.; Kumar, A.; Hira, I.; Ahamad, T.; Ghfar, A. A.; Stadler, F. J. Visible Photodegradation of Ibuprofen and 2,4-D in Simulated Waste Water Using Sustainable Metal Free-Hybrids Based on Carbon Nitride and Biochar. J.ENVIRONM.MGMT 2019, 231, 1164-1175. https://doi.org/10.1016/j.jenvman.2018.11.015.

(5) Mohamed, A.; Salama, A.; Nasser, W. S.; Uheida, A. Photodegradation of Ibuprofen, Cetirizine, and Naproxen by PAN-MWCNT/TiO2-NH2 Nanofiber Membrane under UV Light Irradiation. Environ Sci Eur 2018, 30 (1), 47. https://doi.org/10.1186/s12302-018-0177-6.

(6) Jakimska, A.; Śliwka-Kaszyńska, M.; Reszczyńska, J.; Namieśnik, J.; Kot-Wasik, A. Elucidation of Transformation Pathway of Ketoprofen, Ibuprofen, and Furosemide in Surface Water and Their Occurrence in the Aqueous Environment Using UHPLC-QTOF-MS. Anal Bioanal Chem 2014, 406 (15), 3667-3680. https://doi.org/10.1007/s00216-014-7614-1.

(7) World Health Organization. Pharmaceuticals in Drinking-Water.; World Health Organization: Geneva, Switzerland, 2012.

(8) Awfa, D.; Ateia, M.; Fujii, M.; Johnson, M. S.; Yoshimura, C. Photodegradation of Pharmaceuticals and Personal Care Products in Water Treatment Using Carbonaceous-TiO2 Composites: A Critical Review of Recent Literature. Water Research 2018, 142, 26-45. https://doi.org/10.1016/j.watres.2018.05.036.

(9) Mohan, H.; Lim, J.; Lee, S.; Cho, M.; Park, Y.; Seralathan, K.; Oh, B. V ${ }_{2} \mathrm{O}_{5} / \mathrm{RGO} / \mathrm{Pt}$ Nanocomposite on Oxytetracycline Degradation and Pharmaceutical Effluent Detoxification. J Chem Technol Biotechnol 2020, 95 (1), 297-307. https://doi.org/10.1002/jctb.6238. 
(10) Liu, Y.; He, X.; Fu, Y.; Dionysiou, D. D. Degradation Kinetics and Mechanism of Oxytetracycline by Hydroxyl Radical-Based Advanced Oxidation Processes. Chemical Engineering Journal 2016, 284, 1317-1327. https://doi.org/10.1016/j.cej.2015.09.034.

(11) Poblet, J. M.; López, X.; Bo, C. Ab Initio and DFT Modelling of Complex Materials: Towards the Understanding of Electronic and Magnetic Properties of Polyoxometalates. Chem. Soc. Rev. 2003, 32 (5), 297-308. https://doi.org/10.1039/B109928K.

(12) Valencia, S.; Marín, J. M.; Restrepo, G. Study of the Bandgap of Synthesized Titanium Dioxide Nanoparticules Using the Sol-Gel Method and a Hydrothermal Treatment. TOMSJ 2009, 4 (1), 9-14. https://doi.org/10.2174/1874088X01004010009.

(13) Neumann, R.; Levin, M. Selective Aerobic Oxidative Dehydrogenation of Alcohols and Amines Catalyzed by a Supported Molybdenum-Vanadium Heteropolyanion Salt Na5PMo2V2O40. J. Org. Chem. 1991, 56 (19), 5707-5710. https://doi.org/10.1021/jo00019a047.

(14) Ozer, R. R.; Ferry, J. L. Investigation of the Photocatalytic Activity of TiO2-Polyoxometalate Systems. Environ. Sci. Technol. 2001, 35 (15), 3242-3246. https://doi.org/10.1021/es0106568.

(15) Farsani, M.; Yadollahi, B. Synthesis, Characterization and Catalytic Performance of a Fe Polyoxometalate/Silica Composite in the Oxidation of Alcohols with Hydrogen Peroxide. Journal of Molecular Catalysis A: Chemical 2014, 392. https://doi.org/10.1016/j.molcata.2014.05.001.

(16) Izumi, Y.; Urabe, K. CATALYSIS OF HETEROPOLY ACIDS ENTRAPPED IN ACTIVATED CARBON. Chem. Lett. 1981, 10 (5), 663-666. https://doi.org/10.1246/cl.1981.663.

(17) Ghali, M.; Brahmi, C.; Benltifa, M.; Vaulot, C.; Airoudj, A.; Fioux, P.; Dumur, F.; Simonnet-Jégat, C.; Morlet-Savary, F.; Jellali, S.; Bousselmi, L.; Lalevée, J. Characterization of Polyoxometalate/Polymer Photo-composites: A Toolbox for the Photodegradation of Organic Pollutants. Journal of Polymer Science 2020, pol.20200568. https://doi.org/10.1002/pol.20200568.

(18) Ghali, M.; Brahmi, C.; Benltifa, M.; Dumur, F.; Duval, S.; Simonnet-Jégat, C.; MorletSavary, F.; Jellali, S.; Bousselmi, L.; Lalevée, J. New Hybrid Polyoxometalate/Polymer Composites for Photodegradation of Eosin Dye. Journal of Polymer Science Part A: Polymer Chemistry 2019, 57 (14), 1538-1549. https://doi.org/10.1002/pola.29416.

(19) Brahmi, C.; Benltifa, M.; Ghali, M.; Dumur, F.; Simonnet-Jégat, C.; Monnier, V.; MorletSavary, F.; Bousselmi, L.; Lalevée, J. Polyoxometalate $S$ /Polymer Composites for the Photodegradation of BISPHENOL-A. J Appl Polym Sci 2021, 50864. https://doi.org/10.1002/app.50864. 
(20) Rocchiccioli-Deltcheff, C.; Fournier, M.; Franck, R.; Thouvenot, R. Vibrational Investigations of Polyoxometalates. 2. Evidence for Anion-Anion Interactions in Molybdenum(VI) and Tungsten(VI) Compounds Related to the Keggin Structure. Inorg. Chem. 1983, 22 (2), 207-216. https://doi.org/10.1021/ic00144a006.

(21) Corrales, J.; Kristofco, L. A.; Steele, W. B.; Yates, B. S.; Breed, C. S.; Williams, E. S.; Brooks, B. W. Global Assessment of Bisphenol A in the Environment: Review and Analysis of Its Occurrence and Bioaccumulation. Dose-Response 2015, 13 (3), 155932581559830. https://doi.org/10.1177/1559325815598308.

(22) Ambuludi, S. L.; Panizza, M.; Oturan, N.; Özcan, A.; Oturan, M. A. Kinetic Behavior of Anti-Inflammatory Drug Ibuprofen in Aqueous Medium during Its Degradation by Electrochemical Advanced Oxidation. Environ Sci Pollut Res 2013, 20 (4), 2381-2389. https://doi.org/10.1007/s11356-012-1123-6.

(23) Rivera-Leyva, J.; García-Flores, M.; Valladares-Méndez, A.; Orozco-Castellanos, L.; Martínez-Alfaro, M. Comparative Studies on the Dissolution Profiles of Oral Ibuprofen Suspension and Commercial Tablets Using Biopharmaceutical Classification System Criteria. Indian J Pharm Sci 2012, 74 (4), 312. https://doi.org/10.4103/0250-474X.107062.

(24) Dalkmann, P.; Willaschek, E.; Schiedung, H.; Bornemann, L.; Siebe, C.; Siemens, J. LongTerm Wastewater Irrigation Reduces Sulfamethoxazole Sorption, but Not Ciprofloxacin Binding, in Mexican Soils. J. Environ. Qual. 2014, 43 (3), 964-970. https://doi.org/10.2134/jeq2013.11.0473.

(25) Uncu, L.; Donici, E.; Valica, V.; Vîslouh, O.; Gonciar, V.; Parii, S. Development and Validation of an Assay Method for Ciprofloxacin Hydrochloride Determination in Combination Ear Drops. ChemJMold 2019, 14 (2), 56-61. https://doi.org/10.19261/cjm.2019.607.

(26) PubChem. Oxytetracycline https://pubchem.ncbi.nlm.nih.gov/compound/54675779 (accessed Mar 11, 2021).

(27) Cheng, D.-H.; Yang, S.-K.; Zhao, Y.; Chen, J. Adsorption Behaviors of Oxytetracycline onto Sediment in the Weihe River, Shaanxi, China. Journal of Chemistry 2013, 2013, 1-10. https://doi.org/10.1155/2013/652930.

(28) HERAUX-BOCQUET, J.-C. METEO ALSACE - Retrouvez nos prévisions météo en France et en Alsace à 3 jours ainsi que nos tendances à 3 mois. https://meteoalsace.com/ (accessed Feb 1, 2021).

(29) Thakur, M.; Pandey, S.; Mewada, A.; Patil, V.; Khade, M.; Goshi, E.; Sharon, M. Antibiotic Conjugated Fluorescent Carbon Dots as a Theranostic Agent for Controlled Drug Release, Bioimaging, and Enhanced Antimicrobial Activity. Journal of Drug Delivery 2014, 2014, e282193. https://doi.org/10.1155/2014/282193. 
(30) Lin, C.-C.; Wu, M.-S. Degradation of Ciprofloxacin by UV/S2O82- Process in a Large Photoreactor. Journal of Photochemistry and Photobiology A: Chemistry 2014, 285. https://doi.org/10.1016/j.jphotochem.2014.04.002.

(31) Carlotti, B.; Fuoco, D.; Elisei, F. Fast and Ultrafast Spectroscopic Investigation of Tetracycline Derivatives in Organic and Aqueous Media. Phys. Chem. Chem. Phys. 2010, 12 (48), 15580-15591. https://doi.org/10.1039/C0CP00044B.

(32) Zhang, H.; Liu, D.; Ren, S.; Zhang, H. Kinetic Studies of Direct Blue Photodegradation over Flower-like TiO2. Res Chem Intermed 2017, 43 (3), 1529-1542. https://doi.org/10.1007/s11164-016-2713-6.

(33) Choina, J.; Kosslick, H.; Fischer, Ch.; Flechsig, G.-U.; Frunza, L.; Schulz, A. Photocatalytic Decomposition of Pharmaceutical Ibuprofen Pollutions in Water over Titania Catalyst. Applied

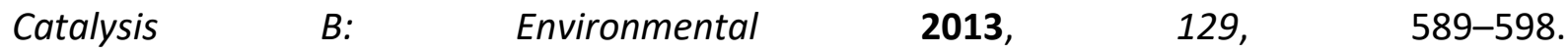
https://doi.org/10.1016/j.apcatb.2012.09.053.

(34) Tian, H.; Fan, Y.; Zhao, Y.; Liu, L. Elimination of Ibuprofen and Its Relative Photo-Induced Toxicity by Mesoporous BiOBr under Simulated Solar Light Irradiation. RSC Adv. 2014, 4 (25), 13061. https://doi.org/10.1039/c3ra47304j.

(35) Uheida, A.; Mohamed, A.; Belaqziz, M.; Nasser, W. S. Photocatalytic Degradation of Ibuprofen, Naproxen, and Cetirizine Using PAN-MWCNT Nanofibers Crosslinked TiO2-NH2 Nanoparticles under Visible Light Irradiation. Separation and Purification Technology 2019, 212, 110-118. https://doi.org/10.1016/j.seppur.2018.11.030.

(36) Tanveer, M.; Guyer, G. T.; Abbas, G. Photocatalytic Degradation of Ibuprofen in Water Using $\mathrm{TiO}_{2}$ and $\mathrm{ZnO}$ under Artificial UV and Solar Irradiation. Water Environment Research 2019, 91 (9), 822-829. https://doi.org/10.1002/wer.1104.

(37) Papaconstantinou, E.; Pope, M. T. Heteropoly Blues. III. Preparation and Stabilities of Reduced 18-Molybdodiphosphates. Inorg. Chem. 1967, 6 (6), 1152-1155. https://doi.org/10.1021/ic50052a019.

(38) Gumerova, N. I.; Rompel, A. Synthesis, Structures and Applications of Electron-Rich Polyoxometalates. Nat Rev Chem 2018, 2 (2), 0112. https://doi.org/10.1038/s41570-0180112.

(39) Vebber, M. C.; da Silva Crespo, J.; Giovanela, M. Self-Assembled Thin Films of $\mathrm{PAA} / \mathrm{PAH} / \mathrm{TiO} 2$ for the Photooxidation of Ibuprofen. Part I: Optimization of Photoactivity Using Design of Experiments and Surface Response Methodology. Chemical Engineering Journal 2019, 360, 1447-1458. https://doi.org/10.1016/j.cej.2018.10.189.

(40) Khalaf, S.; Shoqeir, J. H.; Scrano, L.; Karaman, R.; Bufo, S. A. Photodegradation Using TiO2-Activated Borosilicate Tubes. Environ Sci Pollut Res 2019, 26 (19), 19025-19034. https://doi.org/10.1007/s11356-018-2858-5. 
(41) BethelAnucha, C.; Altin, li.; Bacaksiz, E.; Degirmencioglu, I.; Kucukomeroglu, T.; Yılmaz, S.; Stathopoulos, V. N. Immobilized TiO2/ZnO Sensitized Copper (II) Phthalocyanine Heterostructure for the Degradation of Ibuprofen under UV Irradiation. Separations 2021, 8 (3), 24. https://doi.org/10.3390/separations8030024.

(42) Miranda-García, N.; Maldonado, M. I.; Coronado, J. M.; Malato, S. Degradation Study of 15 Emerging Contaminants at Low Concentration by Immobilized TiO2 in a Pilot Plant. Catalysis Today 2010, 151 (1-2), 107-113. https://doi.org/10.1016/j.cattod.2010.02.044.

(43) Lin, L.; Wang, H.; Jiang, W.; Mkaouar, A. R.; Xu, P. Comparison Study on Photocatalytic Oxidation of Pharmaceuticals by TiO2-Fe and TiO2-Reduced Graphene Oxide Nanocomposites Immobilized on Optical Fibers. Journal of Hazardous Materials 2017, 333, 162-168. https://doi.org/10.1016/j.jhazmat.2017.02.044.

(44) da Silva, J. C. C.; Teodoro, J. A. R.; Afonso, R. J. de C. F.; Aquino, S. F.; Augusti, R. Photolysis and Photocatalysis of Ibuprofen in Aqueous Medium: Characterization of byProducts via Liquid Chromatography Coupled to High-Resolution Mass Spectrometry and Assessment of Their Toxicities against Artemia Salina: Photodegradation of Ibuprofen Monitored by LC-HRMS. J. Mass Spectrom. 2014, 49 (2), 145-153. https://doi.org/10.1002/jms.3320.

(45) Peng, M.; Li, H.; Kang, X.; Du, E.; Li, D. Photo-Degradation Ibuprofen by UV/H2O2 Process: Response Surface Analysis and Degradation Mechanism. Water Sci. Technol. 2017, 75 (12), 2935-2951. https://doi.org/10.2166/wst.2017.149.

(46) Musmarra, D.; Prisciandaro, M.; Capocelli, M.; Karatza, D.; lovino, P.; Canzano, S.; Lancia, A. Degradation of Ibuprofen by Hydrodynamic Cavitation: Reaction Pathways and Effect of Operational Parameters. Ultrasonics Sonochemistry 2016, 29, 76-83. https://doi.org/10.1016/j.ultsonch.2015.09.002.

(47) Arthur, R. B.; Bonin, J. L.; Ardill, L. P.; Rourk, E. J.; Patterson, H. H.; Stemmler, E. A. Photocatalytic Degradation of Ibuprofen over BiOCl Nanosheets with Identification of Intermediates. Journal of Hazardous Materials 2018, 358, 1-9. https://doi.org/10.1016/j.jhazmat.2018.06.018.

(48) Jacobs, L. E.; Fimmen, R. L.; Chin, Y.-P.; Mash, H. E.; Weavers, L. K. Fulvic Acid Mediated Photolysis of Ibuprofen in Water. Water Research 2011, 45 (15), 4449-4458. https://doi.org/10.1016/j.watres.2011.05.041.

(49) Kim, T.-K.; Kim, T.; Cha, Y.; Zoh, K.-D. Energy-Efficient Erythromycin Degradation Using UV-LED $(275 \mathrm{Nm}$ )/Chlorine Process: Radical Contribution, Transformation Products, and Toxicity Evaluation. Water Research 2020, 185, 116159. https://doi.org/10.1016/j.watres.2020.116159. 
(50) Voigt, M.; Jaeger, M. On the Photodegradation of Azithromycin, Erythromycin and Tylosin and Their Transformation Products - A Kinetic Study. Sustainable Chemistry and Pharmacy 2017, 5, 131-140. https://doi.org/10.1016/j.scp.2016.12.001. 